Review Article COVID-19 - Special Issue

\title{
MASPs at the crossroad between the complement and the coagulation cascades - the case for COVID-19
}

\author{
Valéria Bumiller-Bini ${ }^{1,2, *}$ (D), Camila de Freitas Oliveira-Toré3,** (D), Tamyres Mingorance Carvalho ${ }^{4,2}$ (D), \\ Gabriela Canalli Kretzschmar ${ }^{1,2}$ (D), Letícia Boslooper Gonçalves ${ }^{5,2}$ (D), Nina de Moura Alencar ${ }^{6}$ (D), \\ Miguel Angelo Gasparetto Filho ${ }^{1}$ (D), Marcia Holsbach Beltrame ${ }^{1}$ (i) and Angelica Beate Winter Boldt ${ }^{1, *}$ (D) \\ ${ }^{1}$ Universidade Federal do Paraná (UFPR), Departamento de Genética, Laboratório de Genética Molecular \\ Humana, Curitiba, PR, Brazil. \\ ${ }^{2}$ Universidade Federal do Paraná (UFPR), Departamento de Genética, Programa de Pós-Graduação \\ em Genética, Curitiba, PR, Brazil. \\ ${ }^{3}$ Universidade Federal do Paraná (UFPR), Programa de Pós-Graduação em Medicina Interna \\ e Ciências da Saúde, Laboratório de Imunopatologia Molecular, Curitiba, PR, Brazil. \\ ${ }^{4}$ Universidade Federal do Paraná, Departamento de Genética, Laboratório de Citogenética Humana \\ e Oncogenética, Curitiba, PR, Brazil. \\ ${ }^{5}$ Universidade Federal do Paraná (UFPR), Departamento de Genética, Laboratório de Imunogenética \\ e Histocompatibilidade (LIGH), Curitiba, PR, Brazil. \\ ${ }^{6}$ Fundação Oswaldo Cruz (Fiocruz), Instituto Carlos Chagas, Programa de Pós-Graduação \\ em Biociências e Biotecnologia, Laboratório de Virologia Molecular, Curitiba, PR, Brazil.
}

\begin{abstract}
Components of the complement system and atypical parameters of coagulation were reported in COVID-19 patients, as well as the exacerbation of the inflammation and coagulation activity. Mannose binding lectin (MBL)- associated serine proteases (MASPs) play an important role in viral recognition and subsequent activation of the lectin pathway of the complement system and blood coagulation, connecting both processes. Genetic variants of MASP1 and MASP2 genes are further associated with different levels and functional efficiency of their encoded proteins, modulating susceptibility and severity to diseases. Our review highlights the possible role of MASPs in SARS-COV-2 binding and activation of the lectin pathway and blood coagulation cascades, as well as their associations with comorbidities of COVID-19. MASP-1 and/or MASP-2 present an increased expression in patients with COVID-19 risk factors: diabetes, arterial hypertension and cardiovascular disease, chronic kidney disease, chronic obstructive pulmonary disease, and cerebrovascular disease. Based also on the positive results of COVID-19 patients with antiMASP-2 antibody, we propose the use of MASPs as a possible biomarker of the progression of COVID-19 and the investigation of new treatment strategies taking into consideration the dual role of MASPs, including MASP inhibitors as promising therapeutic targets against COVID-19.
\end{abstract}

Keywords: COVID-19, complement system, lectin pathway, MASP, coagulation.

Received: June 18, 2020; Accepted: January 20, 2021.

\section{Introduction}

The emergence of a new infectious agent late in 2019 brought back the attention of the world to the Coronaviridae family (reviewed by Hui et al., 2020; Malik, 2020). In 2003, SARS emerged as a highly infectious disease caused by SARSCoV-1 in Asia (reviewed by Yang et al., 2020). The group of positive-sense RNA viruses took the central spotlight in science and society, after severe acute respiratory syndrome coronavirus 2 (SARS-CoV-2) was identified as the causative agent of the respiratory disease, known as Coronavirus Disease

Send correspondence to Angelica Beate Winter Boldt. Universidade Federal do Paraná (UFPR), Departamento de Genética, Laboratório de Genética Molecular Humana, Avenida Coronel Francisco H. dos Santos, 100, 81531-980, Curitiba, PR, Brazil. E-mail: angelicaboldt@ gmail.com

*These authors contributed equally to this work.
2019 (COVID-19) (reviewed by Brian and Baric, 2005; Zhou et al., 2020c).

In March of 2020, the World Health Organization (WHO) proclaimed a pandemic caused by SARS-CoV-2 (reviewed by Valencia, 2020). COVID-19 ranges from asymptomatic to severe cases and may result in death. The estimated proportion of asymptomatic individuals ranges from 20.6 to $39.9 \%$, with an all-age infectious fatality rate for COVID-19 of $1.3 \%$ (Mizumoto et al., 2020; Russell et al., 2020). In Brazil to date, there are 5,055,888 confirmed cases and 149,639 deaths reported (WHO, 2020a).

SARS-CoV-2 is a positive single-stranded nonsegmented RNA virus with its genome comprised under an envelope covered by glycoproteins, which are potential targets for lectin receptors of the innate immune response (reviewed by Jin et al., 2020). The virus is transmitted primarily via respiratory droplets. Once in contact with the epithelial cell of 
the airways, the interaction between the envelope spike viral glycoprotein (protein S) and components of host cell, such as angiotensin-converting enzyme 2 receptor (ACE-2) and transmembrane serine protease 2 (TMPRSS2), allows it to enter the cell and initiate the viral replicative cycle (Hoffmann et al., 2020; Zhou et al., 2020c). Although particular sites on its glycoprotein spikes are mutated compared to SARS-CoV-1, SARS-CoV-2 uses the same entry receptor and recognizes it with a similar affinity (Shang et al., 2020).

As observed in other coronaviruses infections, the host immune response plays an essential role in defeating the infection. However, it is also associated with tissue damage and disease severity (reviewed by Rabaan et al., 2020). The glycoproteins on the membrane of SARS-CoV-2 represent pathogen-associated molecular patterns (PAMPs), recognized by pattern-recognition receptors (PRRs) of the innate immune response. This response appears to be crucial in the early stages and progression of the disease. Initial innate responses are also based on humoral components, such as cytokines, innate antibodies, and proteins of the coagulation and complement cascades (Matricardi et al., 2020).

This response may eliminate the virus, or, out of control, cause tissue damage and reduced lung capacity (Li et al., 2020; Matricardi et al., 2020; Tay et al., 2020). In fact, damage of the respiratory tract in COVID-19 infection has been rather credited to a dysregulated immune response, than to an amplified viral replication. The activation of lung immune cells by PRRs promotes the release of pro-inflammatory cytokines, neutrophils, and monocytes into the bronchi. This may obstruct the air-blood barrier, causing tissue damage in airway epithelial and vascular endothelial cells, which also express ACE-2 (Risitano et al., 2020).

SARS-CoV-2 infection appears to have a delayed or suppressed Type I IFN response during initial infection, and viral replication triggers a hyperinflammatory state, culminating in a cytokine storm. Severe cases of COVID-19 require access to the intensive care unit. Infected individuals have shown increased levels of different cytokines related to innate immune response, especially interleukin-6 (IL-6) (reviewed by Liu et al., 2020; Prompetchara et al., 2020). IL-6 is mainly produced by activated monocytes and macrophages, as well as by the liver (reviewed by Tanaka et al., 2014). This pro-inflammatory cytokine activates pathways leading to an increased cytokine release, maturation of naïve $\mathrm{T}$ cell, alterations in vessel permeability, heart contractibility, and inflammatory proteins produced by the liver, including complement components (Li et al., 2020; Ye et al., 2020).

SARS-CoV-2 may activate the classical (CP) and lectin (LP) pathways of the complement system (CS) (Matricardi et al., 2020), and LP components were found deposited in lung tissue of COVID-19 patients (Gao et al., 2020b). The CS comprises more than 50 circulating proteins, cell surface receptors and regulators acting at the forefront of the host defense against microorganisms, including the coronaviruses (Ip et al., 2005; Gialeli et al., 2018; Gralinski et al., 2018). It detects and eliminates foreign bodies, clears immune complexes and cell debris, and connects the innate to the adaptive immune responses (reviewed by Ricklin et al., 2016; Gialeli et al., 2018). It is a proteolytic cascade, activated by three distinct pathways: CP, LP and alternative pathway
(AP), which result in the recruitment of inflammatory cells, phagocytosis, neutrophil extracellular traps (NETs) and cell lysis through the membrane-attack complex (MAC, composed by C5b-C9 components) (Ricklin et al., 2016; Bont et al., 2019). Moreover, CS is well-connected with the immune surveillance system, and has an intense crosstalk with other responses, such as the coagulation cascade (reviewed by Ricklin et al., 2016). The dysregulation of complement activity, or its exacerbation, may contribute to tissue damage, leading to inflammatory and immunological diseases (reviewed by Ricklin et al., 2016; Jodele and Köhl, 2020).

All three complement pathways are initiated by different triggers. Depending on the concomitant presence of these triggers on the same surface, all may start simultaneously and compete for central (C3) or terminal (C5-C9) CS components. In this case, inhibition of one pathway may be compensated by another one, with more C3 and C5-C9 at disposal. PRRs with flexible recognition sites within the LP ensure its activation for most (but not all) triggers (reviewed by Beltrame et al., 2015; Ricklin et al., 2016; and Gialeli et al., 2018). This explains why people that present deficiency on one PRR of the LP may still present a working complement system, against most pathogens (Thiel et al., 2007; Ammitzbøll et al., 2013). LP and CP share the same physiological inhibitor (as C1-INH), whereas the alternative pathway depends on factors $\mathrm{B}$ and $\mathrm{H}$ for an efficient inhibition. Since AP mostly depends on spontaneous C3 hydrolysis, complement activation may still occur in the absence of the first two pathways. However, specific inhibition of the LP is not predicted to silence either pathway, neither to exacerbate them, excepting only the aforementioned case with multiple different immunological triggers. On the other hand, AP works as a positive feedback loop for either LP or CP, its inhibition is expected to slow down the CS amplification process (reviewed by Beltrame et al., 2015; Ricklin et al., 2016; and Gialeli et al., 2018).

In the case of COVID-19, the CP of complement can be activated, approximately, one week after virus incubation by the recognition of IgG/IgM-SARS-CoV-2 immune complexes (Wölfel et al., 2020). Yet, LP is the first pathway to get activated after the first contact with the virus, by the binding of mannosebinding lectin (MBL), associated with homodimers of MBLassociated serine proteases (MASPs), to viral N-Glycan or immunocomplexes formed by the IgA immunoglobulin and SARS-CoV-2 (Figure 1). Both activations can lead to cell damage (Matricardi et al., 2020; Jodele and Köhl, 2020).

C3a, C5a and MAC have been found at high levels in COVID-19 patients, increasing with severity of the disease, together with immunoglobulin IgG and $\mathrm{C} 4$ consumption (Gao et al., 2020b; Marcos-Jimenez et al., 2020; Skendros et al., 2020). C5a is a product of C5 cleavage and has a potent chemotactic response, inducing the migration of the neutrophils (Ehrengruber et al., 1994), and the formation of NETs (reviewed by Bont et al., 2019). NET release triggers AP activation through properdin binding (Yuen et al., 2016), and tissue-factor bearing NETs induced by COVID-19 plateletrich plasma launched thrombotic activity of endothelial cells (Skendros et al., 2020), resulting in increased inflammation and coagulation activity. Furthermore, activation of the C5a receptor (C5aR1) leads to inflammasome activation (Jodele and Köhl, 2020). The MASPs of the LP may also activate platelets 


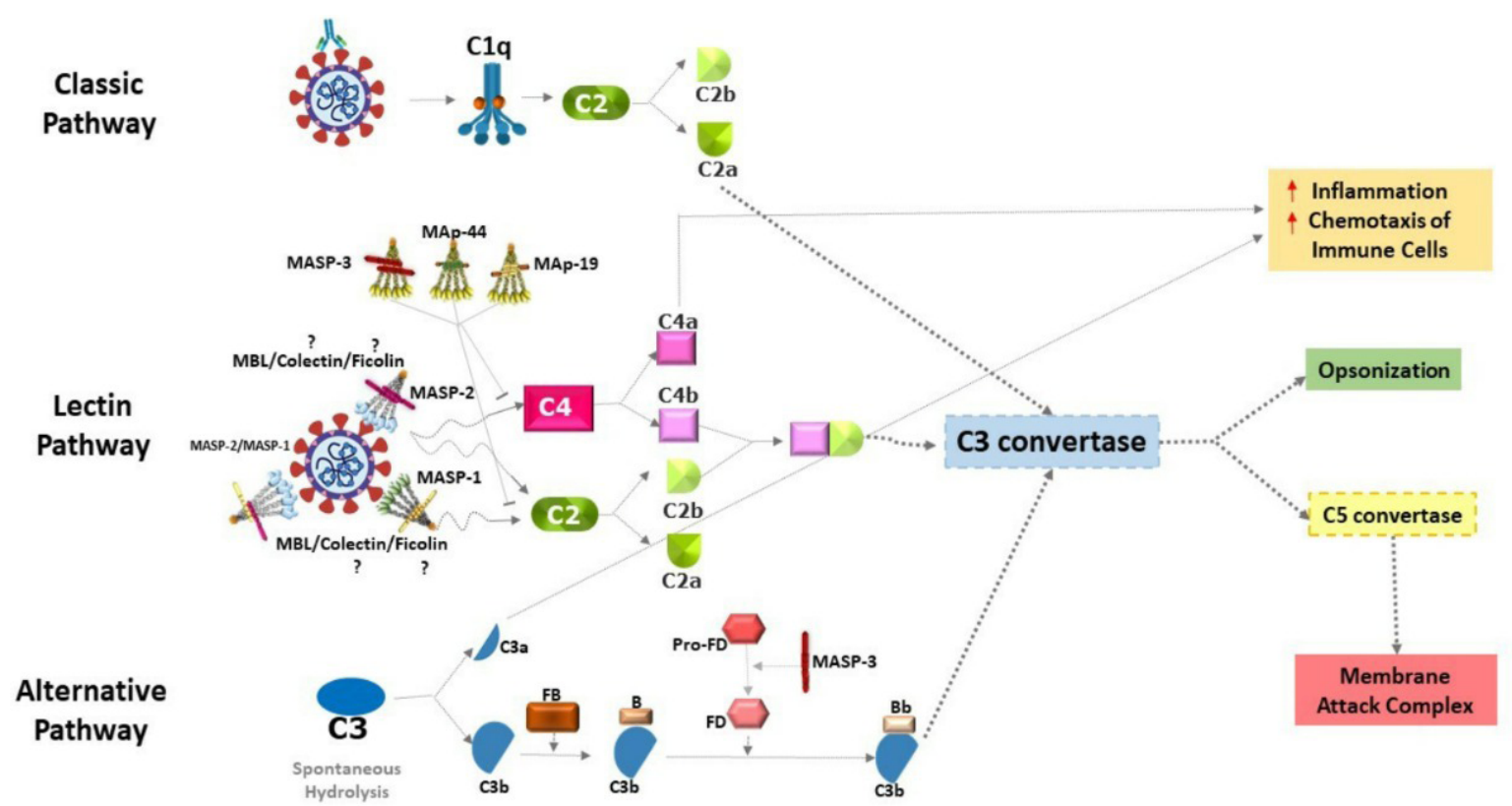

Figure 1 - Complement pathways in SARS-CoV-2 infection. The activation of the classical pathway occurs through the $\mathrm{C} 1$ complex, after recognition of antibodies complexed to SARS-CoV-2. This leads to the cleavage of the $\mathrm{C} 2$ component into $\mathrm{C} 2 \mathrm{a}$ and $\mathrm{C} 2 \mathrm{~b}$. C2a joins the common pathway of the three complement pathways to form the $\mathrm{C} 3$ convertase. Activation of the lectin pathway by the virus via the MBL/MASP-1/MASP-2 complex has already been demonstrated, however the activation by ficolins or colectin is not shown (with a question mark). After binding of MBL/MASP complexes to the surface of pathogens, MASP-1 autoativates, transactivates MASP-2, and $\mathrm{C} 2$ and $\mathrm{C} 4$ components are cleaved (C2 and C4 by MASP-2 and C2 by MASP1), generating the $\mathrm{C} 3$ convertase. The alternative pathway is initiated by the spontaneous hydrolysis of component $\mathrm{C} 3$, generating $\mathrm{C} 3 \mathrm{a}$ and $\mathrm{C} 3 \mathrm{~b}$. $\mathrm{C} 3 \mathrm{~b}$ binds to factor $\mathrm{B}$ and is cleaved by factor $\mathrm{D}$, forming the $\mathrm{C} 3$ convertase of the alternative pathway. After this step, the three pathways converge into a single pathway. The $\mathrm{C} 3$ convertase enzyme cleaves component $\mathrm{C} 3$ into $\mathrm{C} 3 \mathrm{a}$ and $\mathrm{C} 3 \mathrm{~b}$. $\mathrm{C} 3 \mathrm{a}$ and $\mathrm{C} 4 \mathrm{a}$ are anaphylatoxins that contribute to an increase in inflammatory processes and to the chemotaxis of neutrophils and macrophages (red arrows), while C3b performs viral opsonization. The formation of C5 convertase occurs in different ways through the three pathways, but all generate C5a and C5b. C5a is an anaphylatoxin (as also C3a) that contributes to inflammatory processes, while C5b joins the last C6-C9 components of the cascade and forms the membrane attack complex. The MASP-3, MAp44, and probably MAp19 proteins inhibit the lectin pathway. MASP-3 also participates in the cleavage of pro-factor D into factor D, of the alternative pathway. The elements of the figure are not shown in their actual proportions.

and tissue factors, favoring coagulation and microthrombosis. These events are particularly common in the clinical stage of acute respiratory failure, observed in severe cases of the disease (Matricardi et al., 2020)

Indeed, SARS-CoV-2 seems to affect the coagulation cascade (Chen et al., 2020b; Zhou et al., 2020b; Wang et al., 2020b; Tang et al., 2020a; reviewed by Connors and Levy, 2020; Zhang et al., 2020b). Atypical coagulation parameters associated with COVID-19 appeared in early reports from China (Wuhan). Of a total of 99 COVID-19 patients, 6\% had increased activated partial thromboplastin time, $5 \%$ elevated prothrombin and $36 \%$ elevated D-dimer (a protein fragment resulting from clot dissolution) levels. Further, increased concentrations of IL-6 and C-reactive protein and a higher erythrocyte sedimentation rate were reported (Chen et al., 2020b; reviewed by Connors and Levy, 2020). High levels of D-dimer have been associated with increased mortality rates in COVID-19 (Zhou et al., 2020b; Tang et al., 2020b; Zhang et al., 2020b). Its measurement has been suggested as a routine test for an early marker of the disease (pre-print Zhang et al., 2020a).

In this review, we focus on the role of MASPs within the LP and coagulation pathways, and their possible association through genetic polymorphisms, protein levels, and isoforms with COVID-19 and comorbidities, increasing the risk for severe disease, highlighting MASPs as promising biomarkers of disease progression and also as therapeutic targets against COVID-19.

\section{MASPs and the lectin pathway}

The lectin pathway can be activated by PRRs: collectins as MBL and collectin kidney 1 (CL-K1 or CL-11) or ficolins (ficolin-1 or M-ficolin, ficolin-2 or L-ficolin, and ficolin-3 or H-ficolin), associated to homodimers of MASPs (Fujita, 2002; Hansen et al., 2010; Kjaer et al., 2013). The PRRs recognize carbohydrate and acetylated residues on the surface of pathogens and altered cells. After binding, the MASP-1 zymogen autoactivates and transactivates MASP-2. MASP2 further cleaves the $\mathrm{C} 4$ complement component, whereas both MASP-1 and MASP-2 cleave C2. This leads to the formation of the $\mathrm{C} 3$ convertase $(\mathrm{C} 4 \mathrm{bC} 2 \mathrm{~b})$, which is also produced by the initiation of the $\mathrm{CP}$. The $\mathrm{C} 3$ convertase cleaves $\mathrm{C} 3$, a central component of the CS. This cleavage is amplified by the alternative pathway of complement and produces the $\mathrm{C} 3 \mathrm{~b}$ opsonin and the $\mathrm{C} 3 \mathrm{a}$ anaphylatoxin. $\mathrm{C} 3 \mathrm{~b}$ binds to the target surface and results in its opsonization and phagocytosis, thereby promoting the presentation of antigens by phagocytes, initiating adaptive immune responses. The anaphylatoxins include $\mathrm{C} 5 \mathrm{a}$, produced in the final steps of the cascade. They are recognized by specific receptors and active inflammatory responses. The $\mathrm{C} 5$ convertase ( $\mathrm{C} 4 \mathrm{bC} 2 \mathrm{bC} 3 \mathrm{~b}$ ), subsequently cleaves $\mathrm{C} 5$, triggering formation of the membrane attack complex, resulting in cell lysis (Figure 1) (reviewed by Beltrame et al., 2015; Boldt et al., 2016b; Andrade et al., 2017). 
Genetic polymorphisms of the MASP1 and MASP2 genes are associated with low or high protein levels, modulating LP complement activation and susceptibility to diseases (Tables 1 and 2) (Stengaard-Pedersen et al., 2003; Sørensen et al., 2005; Thiel et al., 2007; Thiel et al., 2009; Rooryck et al., 2011; Ammitzbøll et al., 2013; Boldt et al., 2013; Boldt et al., 2016a, b; Krogh et al., 2017). The MASP1 gene (3q27.3) encodes at least three proteins: MASP-1, MASP-3 and mannanbinding lectin-associated protein of $44 \mathrm{KDa}$ (MAp44, also known as MAP-1) (Degn et al., 2009; 2010). The MASP2 gene (1p36.22) encodes MASP-2 and mannan-binding lectin associated protein of $19 \mathrm{kDa}$ (MAp19, also known as SMAP) (Stover et al., 1999). Their highest expression occurs in the liver, except MAp44, which is almost exclusively expressed in the heart (Degn et al., 2009) (Figure 2).

Whereas MASP-1 and MASP-2 activate the LP (Megyeri et al., 2013), MASP-3 cleaves pro-factor D into factor $D$ and activates the AP. It also competes for the same binding sites on PRRs and may thus inhibit LP initiation (Dobó et al., 2016; Garred et al., 2016). On the other hand, MAp44 and MAp19 are truncated proteins that do not have the serine protease domain. MAp44 displaces MASPs from the collagenous stalks of the PRRs and blocks LP activation (Degn et al., 2009), while the function of MAp19 is still unclear, but assumed to be regulatory (Iwaki et al., 2006).

\section{MASPs and the coagulation cascades}

MASPs have key roles in the interaction of the complement system, the coagulation cascade, and fibrinolysis, generating pro-inflammatory and/or pro-thrombotic responses that have not yet been fully elucidated (Hess et al., 2012; Dobó et al., 2014, 2018; Jenny et al., 2019). These components play a critical role in the physiology of comorbidities already associated with the worst prognosis of COVID-19, such as cardiovascular and cerebrovascular diseases, diabetes, metabolic syndrome and disseminated intravascular coagulation (DIC) associated with sepsis (Hess et al., 2012; Dobó et al., 2014; Jenny et al., 2019, Magro et al., 2020).

MASP-1 is the most abundant MASP in human serum. It has a promiscuous catalytic site, being the oldest protease of the CS (Endo et al., 1998; Degn and Thiel, 2013). The configuration of the MASP-1 serine protease domain (SP) differs from the $\mathrm{C} 1 \mathrm{r}$ and $\mathrm{C} 1 \mathrm{~s}$ serine proteases and from other MASPs, being related to thrombin (Degn and Thiel, 2013; Dobó et al., 2014, 2018; Jenny et al., 2015a, b, 2019). In fact, MASP-1 substrates are not restricted to CS components, cleaving substrates as factor XIII (FXIII), quininogen, protease-activated receptor 4 (PAR4) in endothelial cells, prothrombin and the thrombin-activating fibrinolysis inhibiting antifibrinolytic factor (TAFI) (Krarup et al., 2007, 2008; Megyeri et al., 2009b; Dobó et al., 2014, 2018; Jenny et al., 2018, 2019). MASP-1 complexed with ficolins/MBL is directly associated with the formation of clots whose fibrin structure differs from common thrombin-mediated fibrinogen cleavage (Gulla et al., 2010; Takahashi et al., 2011; Hess et al., 2012). It acts in the later stage of clotting, accelerating the clotting process and clot formation in whole blood and platelet-poor plasma - physiological conditions that can be found in many pathologies and infectious diseases, including
COVID-19 (Jenny et al., 2015b, 2019). MASP-1 and thrombin also activate endothelial cells in different ways, preferentially through PAR-4 and PAR-1, respectively (Megyeri et al., 2009a). Through PAR-4 activation, MASP-1 generates a specific pro-inflammatory immune response that promotes neutrophil chemotaxis and stimulates the production of IL-6 and IL-8, also attracting T cells in a severe infection (Dobó et al., 2014; 2018). A response very similar to the one described above has been reported in critically ill patients of COVID-19, however, the origin of this response remains unknown. Likewise, MASP-2 and factor Xa cleave prothrombin to thrombin, but the efficiency of MASP-2 seems to be lower (Krarup et al., 2007) (Figure 3).

The overactivation of coagulation in the initial phase of COVID-19, generating high levels of D-dimers, thrombocytopenia, and moderate prothrombin time prolongation (Thomson et al., 2020), seems to be caused by the combined action of MASP-1/MASP-2 and thrombin. The action of MASP-1 at a later stage may accelerate the time of clot formation, via prothrombin, in platelet-poor whole blood, converging in the formation of D-dimers and clots. Taken together, these data could contribute to explain the high levels of D-dimer and DIC observed in COVID-19 already in the initial phase, associated with new coronavirus pneumonia (NCP) (Jenny et al., 2015a; Tang et al., 2020b).

MASP-1 and MASP-2 have a catalytic role for both prothrombin and fibrinogen, therefore, they have the ability not only to activate the coagulation cascade, but also to contribute along with thrombin to thrombotic complications (Berlin et al., 2020; Jodele and Köhl, 2020) (Figure 4). Anticoagulant therapies with low-molecular weight heparin (LMWH) and antithrombin have shown a major impact on treatment outcome and prevention of DIC associated with COVID-19 (Fogarty et al., 2020; Lin et al., 2020; Ranucci et al., 2020), reducing mortality (Tang et al., 2020a). In the presence of LMWH, antithrombin and C1-INH are effective MASP-1 inhibitors (Dobó et al., 2009; Paréj et al., 2013), blocking both the LP and the cascade of coagulation. C1-INH also blocks MASP2 (Kajdácsi et al., 2020). Interestingly, a deficiency of C1INH is proposed as a direct consequence of SARS-CoV-2 infection, leading to loss of physiological control of LP and coagulation (Thomson et al., 2020). The MASP-2 inhibitor Narsoplimab has similar effects (Rambaldi et al., 2020). Interestingly, MASP-2 inhibitors improved endothelial cell damage in patients with thrombotic microangiopathy, who also presented high MASP-2 levels (Elhadad et al., 2020).

\section{Lectin pathway and coronavirus infection}

The LP is most probably the first to get activated during the incubation stage of SARS-CoV-2 infection, through the recognition of virus proteins by MBL and MASP-2 (Gao et al., 2020b; Magro et al., 2020; Stahel and Barnum, 2020). MBL also binds SARS-CoV-1 S-protein through a N-linked glycosylation site, inhibiting viral infection in susceptible cell lines (Ip et al., 2005; Zhou et al., 2010; Gao et al., 2020b; Jodele and Köhl, 2020). Furthermore, the nucleocapsid (N) protein of SARS-CoV-1, MERS-CoV and SARS-CoV-2 bind to MASP-2, inducing complement hyperactivation (Jodele and Köhl, 2020). Interestingly, the SARS-CoV-2 N-protein 
Table 1 - MASP1 gene polymorphisms associated with MASP-1, MASP-3, and MAp44 serum levels.

\begin{tabular}{|c|c|c|c|c|c|c|c|c|}
\hline dbSNP & Allele & Gene and protein region & $\begin{array}{l}\text { Amino acid } \\
\text { position }\end{array}$ & $\begin{array}{c}\text { AF } \\
\text { Brazilian }^{1} \\
\%\end{array}$ & $\begin{array}{c}\text { AF AFR } \\
\%\end{array}$ & $\begin{array}{c}\text { AF EUR } \\
\%\end{array}$ & $\begin{array}{l}\text { AF EAS } \\
\%\end{array}$ & Serum levels* \\
\hline rs190590338 & $\mathrm{G}>\mathbf{A}$ & Promoter - n.a & n.a. & n.o. & 0 & $<1$ & 0 & $\begin{array}{l}\text { Higher MASP-1 levels in G/A } \\
\text { (Ammitzbøll et al., 2013) }\end{array}$ \\
\hline rs7625133 & $\mathrm{A}>\mathbf{C}$ & Promoter - n.a & n.a. & n.o. & 2.4 & 6.4 & $<1$ & $\begin{array}{c}\text { Lower MAp44 levels in A/C } \\
\text { and } \mathrm{C} / \mathrm{C}(\text { Ammitzbøll } \\
\text { et al., 2013) }\end{array}$ \\
\hline rs35089177 & $\mathbf{T}>\mathrm{A}$ & Promoter - n.a & n.a. & n.o. & 6.3 & 34.3 & 38 & $\begin{array}{c}\text { Lower MASP-1 and MAp44 } \\
\text { levels in T/A and AA } \\
\text { (Ammitzbøll et al., 2013) }\end{array}$ \\
\hline rs75284004 & $\mathrm{A}>\mathbf{G}$ & Promoter - n.a & n.a. & n.o. & $<1$ & 4.1 & $<1$ & $\begin{array}{l}\text { Lower MASP-3 levels in A/G } \\
\text { (Ammitzbøll et al., 2013) }\end{array}$ \\
\hline rs62292785 & $\mathrm{G}>\mathbf{A}$ & Promoter - n.a & n.a. & n.o. & 4.8 & 5.6 & 18.8 & $\begin{array}{l}\text { Lower MASP-1 levels in G/A } \\
\text { (Ammitzbøll et al., 2013) }\end{array}$ \\
\hline rs72549254 & $\mathrm{G}>\mathbf{A}$ & Intron 1 - n.a & n.a. & 13.3 & 21.9 & 13.9 & 11.7 & $\begin{array}{c}\text { Higher MASP-3 levels in A/G } \\
\text { (Ammitzbøll et al., 2013) } \\
\text { Lower MAp44 levels in A/G } \\
\text { and A/A(Ammitzbøll } \\
\text { et al., 2013) } \\
\text { Lower MAp44 levels in G/G } \\
\text { (Krogh et al., 2017) }\end{array}$ \\
\hline rs710469 & $\mathrm{C}>\mathbf{T}$ & Intron $2-$ n.a & n.a. & n.o. & 35.4 & 50.5 & 51.1 & $\begin{array}{c}\text { Higher on-admission MASP-3 } \\
\text { levels in critically ill children } \\
\text { with T/T (Ammitzbøll et al., } \\
\text { 2013) }\end{array}$ \\
\hline rs3774275 & $\mathrm{A}>\mathbf{G}$ & Intron $8-$ n.a & n.a. & 18.5 & 2.1 & 30.8 & 41.8 & $\begin{array}{l}\text { Higher MASP-1, Map44 and } \\
\text { lower MASP-3 levels in A/G } \\
\text { and G/G (Ammitzbøll } \\
\text { et al., 2013) } \\
\text { Lower MASP-1 and MAp44 } \\
\text { levels in A/A (Krogh } \\
\text { et al., 2017) }\end{array}$ \\
\hline rs113938200 & $\mathrm{C}>\mathbf{T}$ & $\begin{array}{l}\text { Exon } 9 \text { - C-terminal MAp- } \\
44\end{array}$ & p.Asn368Asp & $<1$ & 0 & $<1$ & 0 & $\begin{array}{l}\text { Lower MAp44 levels in C/T } \\
\text { (Ammitzbøll et al., 2013) }\end{array}$ \\
\hline rs698090 & $\mathbf{C}>\mathrm{T}$ & Exon 9 - 3’UTR Map-44 & n.a. & 37.4 & 62.4 & 35.8 & 37.6 & $\begin{array}{c}\text { Higher MASP-1, MAp44 and } \\
\text { lower MASP-3 levels in C/C } \\
\text { (Ammitzbøll et al., 2013) } \\
\text { Higher MAp44 levels in C/T } \\
\text { (Ammitzbøll et al., 2013) }\end{array}$ \\
\hline rs72549154 & $\mathrm{G}>\mathbf{T}$ & Exon 12 - SP MASP-3 & p.Arg576Met & $<1$ & 15.1 & 2.5 & $<1$ & $\begin{array}{l}\text { Lower MASP-1 levels in G/T } \\
\text { (Ammitzbøll et al., 2013) }\end{array}$ \\
\hline rs850312 & $\mathrm{G}>\mathbf{A}$ & Exon 12 - CCP2 MASP-3 & p.Leu617Leu & 27.2 & 2.6 & 34.8 & 20.3 & $\begin{array}{l}\text { Higher on-admission MASP-3 } \\
\text { levels in critically ill children } \\
\text { with A/A, A/G (Ammitzbøll et } \\
\text { al., 2013) Lower MASP-3 and } \\
\text { higher Map44 levels in G/G } \\
\text { (Krogh et al., 2017) }\end{array}$ \\
\hline rs67143992 & $\mathrm{G}>\mathbf{A}$ & Exon12 - 3'UTR MASP-3 & n.a. & 12.9 & 1.4 & 16.9 & 4.5 & $\begin{array}{c}\text { Higher MASP-1, MAp44 and } \\
\text { lower of MASP-3 levels in } \\
\text { G/A (Ammitzbøll } \\
\text { et al., 2013) } \\
\text { Higher MAp44 and lower } \\
\text { MASP-3 levels in A/A } \\
\text { (Ammitzbøll et al., 2013) } \\
\text { Lower MASP-3 levels in A/A } \\
\text { (Krogh et al., 2017) }\end{array}$ \\
\hline rs874603 & $\mathbf{G}>\mathrm{A}$ & 3'UTR MASP-3 & n.a. & 12.4 & 36.2 & 5.7 & 0.8 & $\begin{array}{c}\text { Higher MASP-3 levels in G/A } \\
\text { (Krogh et al., 2017) }\end{array}$ \\
\hline
\end{tabular}

dbSNP: Single Nucleotide Polymorphism Database; n.o.: no data; n.a.: not applicable; AF: allele frequency of 1000 genomes project from AFR, EUR and EAS; AFR: African, EUR: European, and EAS: East Asian (data accessed on: https://www.ensembl.org/index.html); CCP: Complement Control Protein; SP: Serine Protease; UTR: untranslated. *compared to the homozygote state of the other allele. Alleles in bold are considered the minor alleles in the global population. Serum levels are related to this allele. SNPs in bold are considered expression quantitative trait loci (eQTLs), due to their association with mRNA expression. (http://www.gtexportal.org/home/eqtls/byGene?geneId=MASP1\&tissueName=All) ${ }^{1}$ data from ABraON (http://abraom.ib.usp. br/index.php). Table modified from Boldt et al., 2016a. 
Table 2 - MASP2 gene polymorphisms associated with MASP-2 and MAp19 serum levels.

\begin{tabular}{|c|c|c|c|c|c|c|c|c|}
\hline dbSNP & Allele & $\begin{array}{c}\text { Gene and } \\
\text { protein region }\end{array}$ & $\begin{array}{l}\text { Amino acid } \\
\text { position }\end{array}$ & $\begin{array}{c}\text { AF Brazilian } \\
\%\end{array}$ & $\begin{array}{c}\text { AF AFR } \\
\%\end{array}$ & $\begin{array}{c}\text { AF EUR } \\
\%\end{array}$ & $\begin{array}{c}\text { AF EAS } \\
\%\end{array}$ & Serum levels* \\
\hline rs7548659 & $\mathbf{G}>\mathrm{T}$ & Promoter - n.a & n.a. & 29.3 & 82.8 & 21.9 & 26.1 & $\begin{array}{l}\text { high MASP-2 and low MAp19 concentration } \\
\text { (Boldt et al., 2013) }\end{array}$ \\
\hline rs61735600 & $\mathrm{C}>\mathbf{T}$ & Exon 3 - CUB1 & p.R99Q & 1.3 & 7.1 & 0 & 0 & high MASP-2 concentration (Thiel et al., 2007) \\
\hline rs 72550870 & $\mathrm{~T}>\mathbf{C}$ & Exon 3 - CUB1 & p.D120G & 1.4 & $<1$ & 3.9 & 0 & $\begin{array}{l}\text { low MASP-2 and MAp19 concentration } \\
\text { (Stengaard-Pedersen } \text { et al., 2003; Sørensen } \\
\text { et al., 2005; Thiel et al., 2007; } \\
\text { Boldt et al., 2013) }\end{array}$ \\
\hline rs56392418 & $\mathrm{C}>\mathbf{T}$ & Exon 3 - CUB1 & p.P126L & 0.5 & 13.2 & 0 & 0 & low MASP-2 concentration (Thiel et al., 2009) \\
\hline rs2273343 & $\mathrm{T}>\mathbf{C}$ & Exon 4 - EGF & p.H155R & n.o. & 0 & 0 & 2.7 & low MASP-2 concentration (Thiel et al., 2009) \\
\hline rs2273344 & $\mathbf{C}>\mathrm{T}$ & Intron $4-$ n.a & n.a. & 18.6 & 10.1 & 20.4 & 11.8 & $\begin{array}{l}\text { high MASP-2 and low MAp19 concentration } \\
\text { (Boldt et al., 2013) }\end{array}$ \\
\hline rs9430347 & $\mathrm{G}>\mathbf{A}$ & Intron 5 - n.a & n.a. & 18.6 & 9.2 & 20.4 & 11.6 & $\begin{array}{l}\text { high MASP-2 and low MAp19 concentration } \\
\text { (Boldt et al., 2013) }\end{array}$ \\
\hline rs17409276 & $\mathrm{G}>\mathbf{A}$ & Intron $9-$ n.a & n.a. & 14.7 & 16.6 & 13.8 & 13.6 & $\begin{array}{l}\text { high MASP-2 and low MAp19 concentration } \\
\text { (Boldt et al., 2013) }\end{array}$ \\
\hline rs12711521 & $\mathbf{C}>\mathrm{A}$ & $\begin{array}{l}\text { Exon } 10- \\
\text { CCP2 }\end{array}$ & p.D371Y & 22.9 & 82.9 & 18 & 33.4 & $\begin{array}{l}\text { high MASP-2 and low MAp19 concentration } \\
\text { (Boldt et al., 2013) }\end{array}$ \\
\hline rs2273346 & $\mathrm{A}>\mathbf{G}$ & $\begin{array}{l}\text { Exon } 10- \\
\text { CCP2 }\end{array}$ & p.V377A & 3.4 & 17.1 & 2 & 19.8 & $\begin{array}{l}\text { low MASP-2 concentration (Thiel et al., } \\
\text { 2007; Thiel et al., 2009) }\end{array}$ \\
\hline rs12085877 & $\mathrm{G}>\mathbf{A}$ & Exon $12-\mathrm{SP}$ & p.R439H & 0.1 & 10.4 & 0 & 0 & low MASP-2 concentration (Thiel et al., 2009) \\
\hline rs1782455 & $\mathbf{G}>\mathrm{A}$ & Exon $12-\mathrm{SP}$ & p.S493= & 19.5 & 70.3 & 16 & 13.5 & $\begin{array}{l}\text { high MASP-2 and low MAp19 concentration } \\
\text { (Boldt et al., 2013) }\end{array}$ \\
\hline
\end{tabular}

dbSNP: Single Nucleotide Polymorphism Database; n.o.: no data; n.a: not applicable; AF: allele frequency of 1000 genomes project from AFR, EUR and EAS; AFR: African, EUR: European, and EAS: East Asian (data accessed on: https://www.ensembl.org/index.html); CCP: Complement Control Protein; SP: Serine Protease, EGF: epidermal growth factor. *Homozygote of the allele effect. Alleles in bold are considered the minor AF in global population and the serum levels are related to this allele. SNPs in bold are considered expression quantitative trait loci (eQTLs), due to their association with mRNA expression (http://www.gtexportal.org/home/eqtls/byGene?geneId=MASP2\&tissueName=All). ${ }^{1}$ data from predominantly Euro-Brazilian healthy volunteers (Boldt et al., 2016a). Table modified from Boldt et al., 2016a.
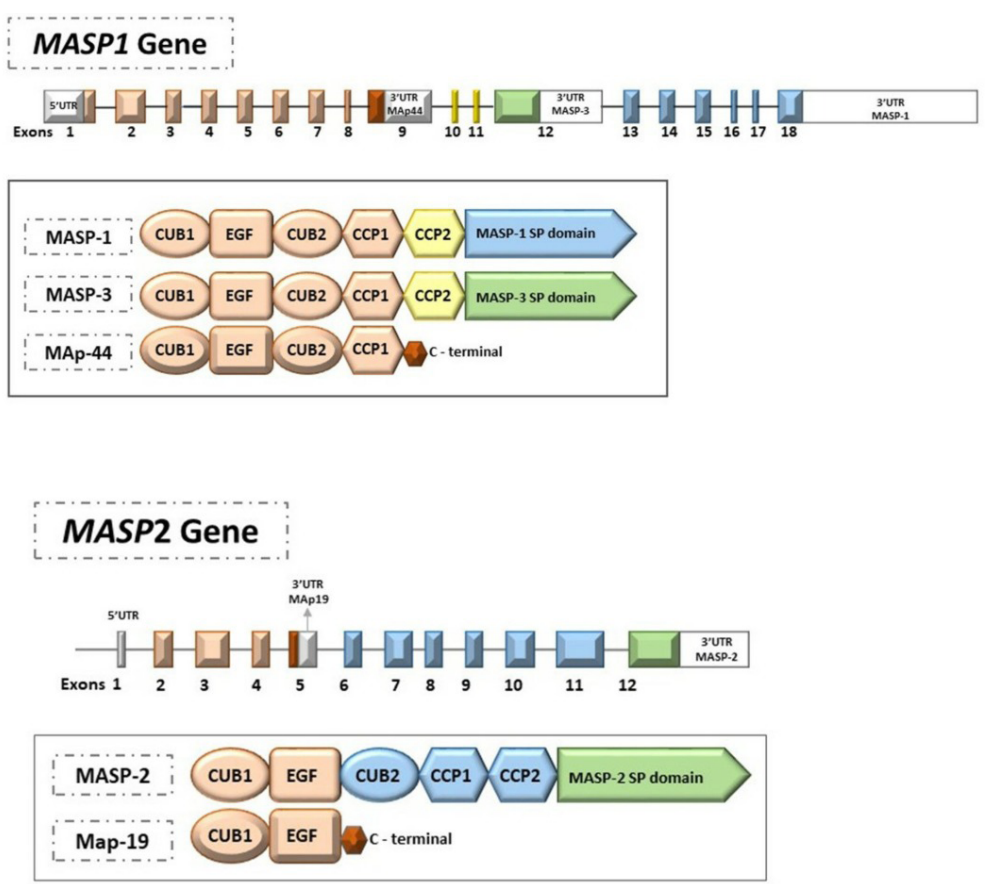

Figure 2-MASP1 and MASP2 genes. The MASP1 gene (ENSG00000127241) generates three proteins by alternative splicing: MASP-1 (ENST00000337774.9), MASP-3 (ENST00000296280.11) and MAp44 (ENST00000169293.10). MASP-1 and MASP-3 share the regulatory domains (CUB1-EGF-CUB2-CCP1CCP2), but differ in the serine protease domain (SP); MASP-1 SP is encoded by exons 13 to 18, whereas the MASP-3 SP is encoded only by exon 12 . MAp44 lacks the SP domain but shares the first four domains with MASP-1 and MASP-3 (CUB1-EGF-CUB2-CCP1). This protein has no protease function. The MASP2 gene (ENSG00000009724) encodes two proteins: MASP-2 (ENST00000400897.8) and MAp19 (ENST00000400898.3). MASP-2 and MAp19 share only two regulatory domains (CUB1-EGF). MASP-2 has a SP domain, but MAp19 lacks this domain. Genetic polymorphisms in these two genes can alter protein expression (see Tables 1 and 2), and many have already been associated with the most diverse disease models. Exons and introns are represented figuratively, not reflecting their actual size. The same colors represent the domains and their respective exons. Figure adapted from Boldt et al. (2016). 


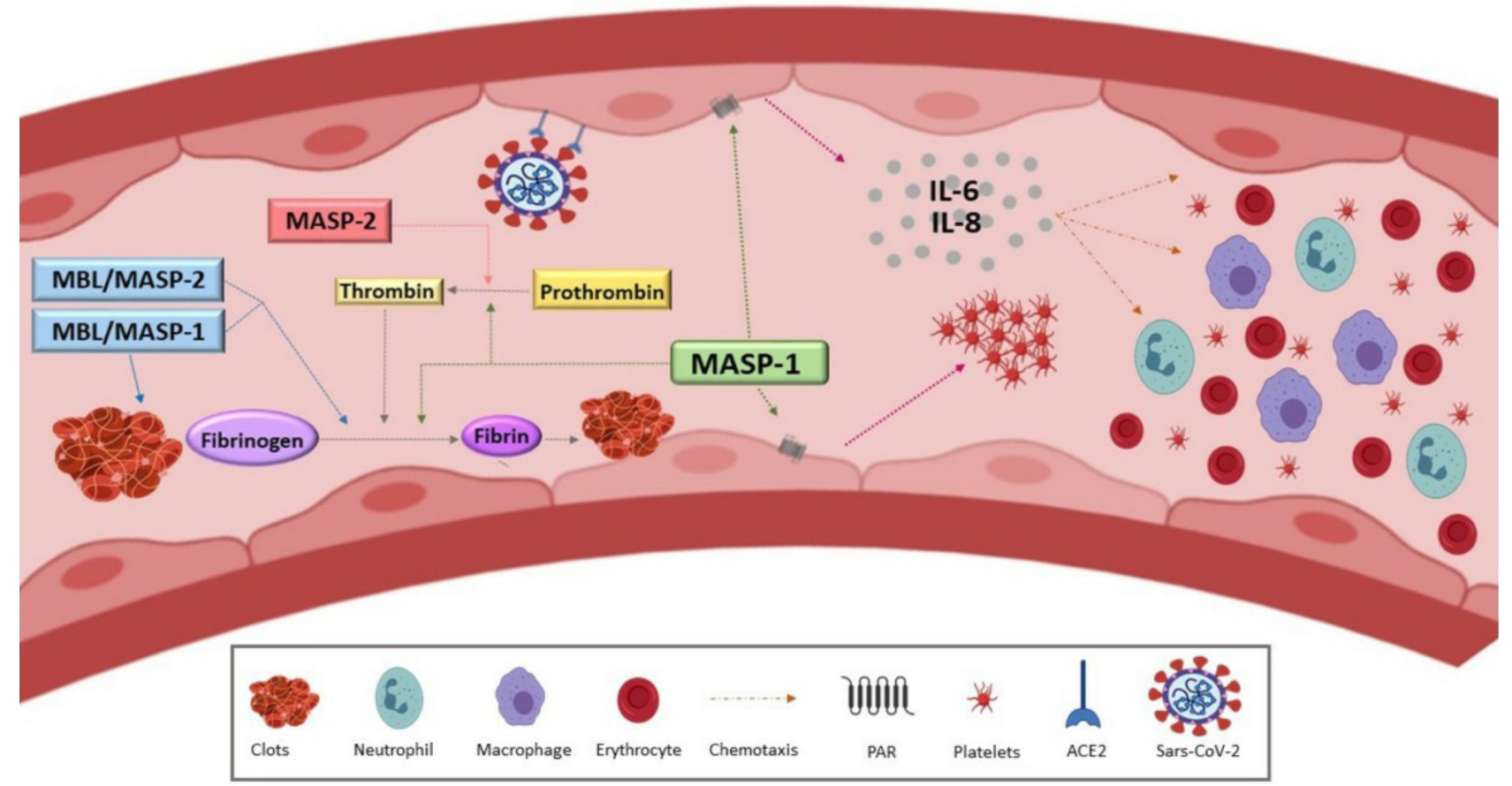

Figure 3 - MASPs in the coagulation cascade during COVID-19. The participation of MASPs in coagulation contributes significantly to the formation of clots, and cleavage of intermediate components of the cascade. On the right side of the figure, MASP-1 activates endothelial cells through the protease-activated receptor (PAR) 4, 2 and 1. This activation has a characteristic response profile, and different from that stimulated via thrombin: activated endothelial cells start secretin pro-inflammatory cytokines and interleukins 6 and 8 (IL-6 and IL-8). Platelet aggregation also occurs. IL-6 and IL-8 contribute to the chemotaxis of neutrophils and macrophages. On the left, complexes of MASPs and MBL / MASPs participate in the coagulation cascade at different points. Like the factor Xa (FXa) of the coagulation cascade, MASP-2 cleaves prothrombin to thrombin 1. MASP-1 participates in the cleavage of prothrombin to thrombin, and the cleavage of fibrinogen to fibrin. MASP-1 cleaves prothrombin in three specific sites: R393, R155, and R271. The sites R155 and R271 are shared with thrombin and factor FXa, respectively, whereas R393 is exclusive of MASP-1. MBL/MASPs complexes form clots directly, without co-participation of other components of coagulation (Gulla et al., 2010). These complexes cleave fibrinogen to fibrin, contributing to formation of clots in the coagulation cascade. MASP-1 has an independent dual role in the coagulation cascade and innate immunity. Its important contribution to the coagulation cascade and the time/structure of the clots can contribute to direct the pathophysiology of COVID-19 to severe conditions.

A

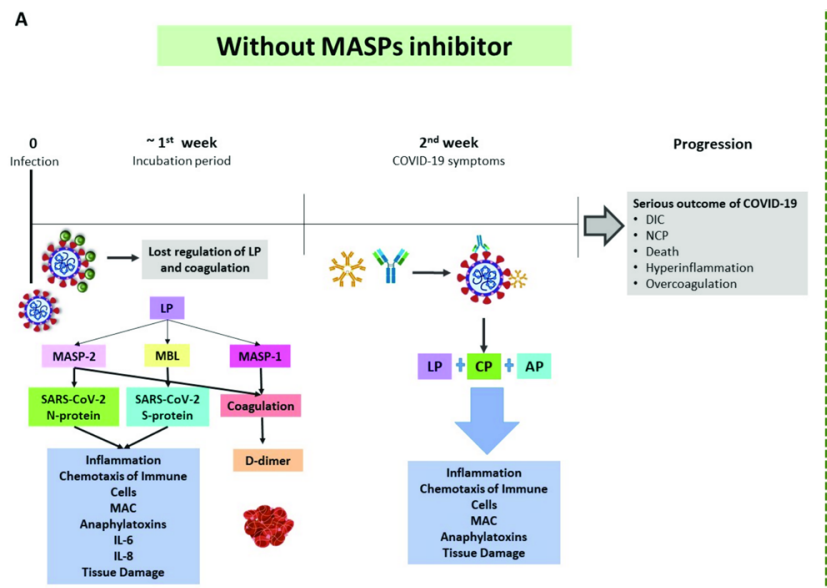

B

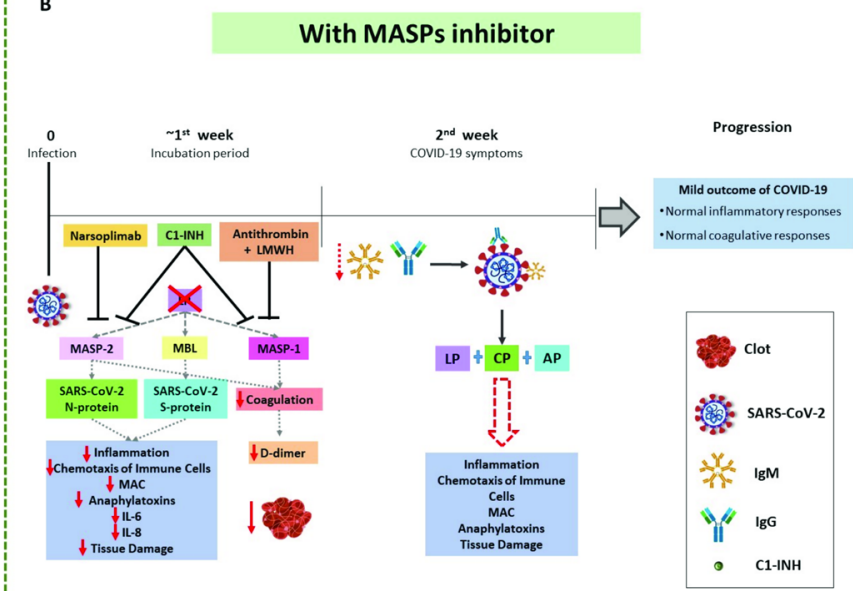

Figure 4 - Promising therapeutic targets. (A) The clinical symptoms of COVID-19 appear after the first week of infection. In this first week, MASP2 recognizes the N-SARS-CoV-2 protein and MBL recognizes S-SARS-CoV-2, leading to lectin pathway (LP) activation. Deficiency of C1-INH, proposed as a direct consequence of SARS-CoV-2 infection, leads to loss of physiological control of LP and coagulation, causing hyperinflammation and overcoagulation. During the second week, the symptoms start with activation of the classical pathway (CP) through the production of IgG and IgM antibodies, amplified by the alternative pathway (AP). At this stage of the disease, uncontrolled complement activation of all three pathways contribute to worsen the prognosis of COVID-19. (B) Drugs that inhibit the LP of complement can be considered as promising therapeutic agents against COVID-19. Those that inhibit MASP-1 and/or MASP-2 (Narsoplimab, C1-INH and antithrombin in the presence of low-molecular weight heparin - LMWH) are predicted to block both LP and coagulation, redirecting the clinical course of COVID-19 towards a better prognosis. This may also occur by reducing excessive antibody production, due to lower viral opsonization, phagocytosis and antigen presentation to B lymphocytes. AP - alternative pathway of complement; DIC - disseminated intravascular coagulation; C1-INH - C1 inhibitor; CP - classical pathway of complement; Ig - immunoglobulins; IL - interleukin; LP - lectin pathway of complement; MAC - membrane attack complex; MASP - mannose-binding lectin associated serine protease; NPC - new coronavirus pneumonia. Traced lines - weakened or blocked activation/ production. Solid lines - activation or blockage. Down-pointing arrows - lower production. 
does also interact with MAp19 (Liu et al., 2009). The CP and AP are activated a few days later after production of $\mathrm{C} 3 \mathrm{~b}$ and antibodies, respectively, but antibody production may be compromised due to lymphocytopenia (Berlin et al., 2020; Stahel and Barnum, 2020; Matricardi et al., 2020) (Figures 1 and 5). In accordance with these findings, MASP-2, as well as MBL, C4a, C4, and C5b-9, accumulate in lung tissue of COVID-19 patients (Gao et al., 2020b). The lung microvasculature of severe COVID-19 cases also present deposits of MASP-2, C5b-9 and C4d (Magro et al., 2020). Thus, the LP seems to drive the primary immune response against SARS-CoV-2, but on the other hand, its chronic activation contributes to worsen COVID-19 symptoms (Eriksson et al., 2019; Gao et al., 2020b; Magro et al., 2020).

\section{Polymorphisms and protein levels of MASPs and coronavirus infection}

$M A S P 1$ and $M A S P 2$ polymorphisms are associated with protein levels and with the susceptibility to different viral infections (reviewed by Beltrame et al., 2015) (Tables 1 and 2). MASP2 polymorphisms rs2273346 (p.Val377Ala) and rs12711521 (p.Asp371Tyr) were investigated regarding susceptibility to SARS-CoV-1 infection, but no association was found (Wang et al., 2009). The absence of association may be due to the lack of investigation of common MASP2 intronic regulatory variants, which present a much higher associated effect on MASP-2/MAp19 levels (rs2273344, rs9430347 and rs 17409276) (Boldt et al., 2013) (Table 2). Thus, the role of the MASP2 gene polymorphisms in SARS-CoV-2, such as of other CS genes, remains unclear.

To date, neither MASP-1 concentrations nor MASP1 polymorphisms have been investigated in the inflammatory and/or hematological processes of COVID-19. Unlike other CS components already associated with COVID-19, routine analysis of hospitalized patients for the presence/concentration of MASP-1 has not been carried out (Magro et al., 2020). However, since MASP-2 strictly depends on MASP-1 for LP activation, and given its important role linking the LP to the coagulation cascade and association with many of the factors/comorbidities increasing the risk for severe COVID-19 disease (see below), we strongly suggest both as major candidates for further functional and genetic association studies in coronaviral diseases (polymorphisms listed on Tables 1 and 2). Furthermore, complement-induced lung injury may be attenuated by blocking the N-protein/MASP2 interaction and/or by complement suppression itself, as suggested by data in vitro and in vivo (Gao et al., 2020b). In this context, coding polymorphisms may hinder recognition by monoclonal antibodies. This has been described for anti-C5 drugs (Nishimura et al., 2014), and may be theoretically possible for any coding polymorphism in the $M A S P 1$ and $M A S P 2$ genes, as well. In the case of the MASP-2 inhibitor already being used in compassionate treatment (Rambaldi et al., 2020), their impact will be important for MASP2 p.Y371D (rs12711521), whose frequency of homozygotes reaches 25\% in major human groups, but will be negligible for rare variants and those already reducing or abrogating protein function, as p.D120G (rs72550870) and p.R439H (rs12085877), and perhaps p.P126L (rs56392418), which may cooccur with
p.439H in the *1C2-l [AG] haplotype (Boldt et al., 2013) and p.V377A (rs2273346) (see populational frequencies in Table 2).

MASPs are actually predicted to get engaged with the virus as soon as it enters peripheral circulation, either by directly attaching to it (MASP-2), or as homodimers connected to PRRs that recognize sugar and acetylated moieties at the viral surface (Gao et al., 2020b; Jodele and Köhl, 2020; Świerzko and Cedzyński, 2020). They may be explored as biomarkers for disease progression. Decreasing MASP levels may predict increasing disease severity, due to the enrollment of MASPs in the coagulation and complement cascades, as well as in phagocytic engulfment of opsonized particles, exacerbating inflammation. In fact, lower MASP-2, MASP-3 and MAp44 levels occur in leprosy and lepromatous disease, probably due to its consumption in the inflammatory response. On the other hand, MASP1 haplotypes associated with lower MASP-1 and higher MASP-3 levels at baseline were associated with leprosy resistance, probably by decreasing mycobacteria infection, which relies on successful complement-driven opsonization and phagocytosis (Boldt et al., 2013; Weinschutz Mendes et al., 2020). Thus, the investigation of MASP levels in COVID-19 is also highly relevant, especially in the context of comorbidities.

\section{Complement-targeted therapies}

Due to the high pleiotropy of genes encoding complement components, it is impossible to predict precisely the effect of inhibiting one of its molecules. This challenge however, has been partly overcome with animal models. In the case of mice infected with mouse adapted SARS-CoV-1, weight loss and respiratory dysfunction was reduced by $\mathrm{C} 3$ complement knock-out, although viral loads did not differ in the lungs of wild-type and C3 knock-out mice (Gralinski et al., 2018). Decreased disease severity was also found after complement inhibition with an anti-C5a reagent in the MERS-CoV human DPP4 transgenic mouse model (Jiang et al., 2018). Interestingly, both C3 (compstatin-based C3-targeted drug candidate AMY-101) and C5 (Eculizumab) inhibitors enhanced lung function concomitant with a steep decline in C-reactive protein and IL-6 levels. However, C3 inhibition also reduced $\mathrm{C} 3 \mathrm{a}$ and $\mathrm{sC} 5 \mathrm{~b}-9$ generation and prevented factor $\mathrm{B}$ (of the AP) consumption (Mastellos et al., 2020). It may also disrupt tissue factor expression in neutrophils (Skendros et al., 2020). This broader C3inh-dependent therapeutic control was also reflected by lower neutrophil counts and less NET release, stronger lymphocyte recovery and faster serum lactate dehydrogenase (LDH) decline (Mastellos et al., 2020). The usage of C3 and C5 inhibitors is currently being tested in six different clinical trials registered in the ClinicalTrials.gov database and presents a high therapeutic potential (Lo et al., 2020).

Unlike these, MASP-2 blockage is not expected to interrupt CP (Figure 4). Even so, usage of an anti-MASP-2 human monoclonal antibody (Narsoplimab) on six Italian patients with COVID-19 acute respiratory distress syndrome (ARDS) was highly effective, without any measurable colateral effect, achieving fast and sustained reduction of circulating endothelial cells (a marker of vascular damage) and concomitant reduction of serum IL-6, IL-8, C-reactive protein (CRP) and LDH (Rambaldi et al., 2020). In comparison, C5 and C3 inhibition (e.g. with Eculizumab) are effective in blocking 
formation of the $\mathrm{C} 5$ convertase, the $\mathrm{C} 5 \mathrm{a}$ anaphylatoxin and the membrane attack complex, which are terminal steps achieved by all complement initiating pathways (Laurence et al., 2020; Mastellos et al., 2020). However, both would not necessarily affect the coagulation cascade. In the case of COVID-19, blocking LP through a MASP inhibitor may suffice to inhibit hyperinflammation and microcoagulation events, because (1) this pathway appears to be the first to get activated in contact with the virus, (2) MASPs activate key arms of the coagulation cascade and (3) MASP2 can recognize SARS-Cov-2 viral N protein. In fact, although all three strategies target CS components with the potential to control hyperinflammation, only the MASP inhibitors have the ability to control hyperinflammation, clotting and viral recognition at once (Figure 4). In fact, Narsoplimab blocks MASP-2-mediated activation of kallikrein and factor XII and consequent microvascular thrombosis, benefitting patients with massive pulmonar thrombotic events. It cannot block extracellular matrix-related, factor VII-driven, coagulation and does not prolong bleeding time nor affect prothrombin or activated partial thromboplastin times (Demopulos et al., 2020; Omeros Corporation, 2013a, b; 2019). Furthermore, the broader action of $\mathrm{C} 5$ inhibition on complement increases susceptibility to opportunistic pathogens as Neisseria meningitidis, even in vaccinated individuals (Langereis et al., 2020). Thus, combining complement-inhibiting strategies would expose the patients to unnecessary risks, and unilateral inhibition of just LP, which seems to be the major complement pathway in the disease, would preserve most needed complement-provided bridges to a well-regulated adaptive immune response. Caution must be nevertheless observed at this point, since we partly build our assumptions on basic science and partly on pioneering clinical interventions. More translational studies are undoubtedly needed to arrive at a better therapeutic strategy in patients with COVID-19.

\section{MASPs and COVID-19 risk factors}

\section{Age and sex}

Age and sex are well-known aspects that could impact the quality of the immune response (Giefing-Kröll et al., 2015; Gaya da Costa et al., 2018). A study performed with Chinese patients with COVID-19 revealed that $0.9 \%$ of the patients were younger than 15 years of age, and $15.1 \%$ had more than 65 years (Guan et al., 2020). Impressively, the median age of the patients with severe cases was higher, and more than half of patients $(58.3 \%)$ who developed severe symptoms were over 50 years old. Just $12.9 \%$ of those without severe disease were more than 65 years old (Guan et al., 2020), and symptoms presented a slow course in children compared to infected adults (Lu et al., 2020). In a Brazilian study with 510 COVID-19 patients, the average age was 40 years. Only $0.6 \%$ of patients were under 11 years old, and $6.5 \%$ were over 65 years old (Teich et al., 2020).

Although neonatal innate immunity is focused on protection against extracellular pathogens instead of intracellular bacteria and viruses (Prendergast et al., 2012), elderly usually have just $1 \%$ of new $\mathrm{T}$ cell production compared to a child (Vallejo, 2006; Chinn et al., 2012). Thus, older adults are more susceptible to infections, mainly due to the reduction of efficiency and coordination of immune response, added to comorbid conditions, and the simultaneous use of multiple drugs (Weng, 2006; Shaw et al., 2013; Nikolich-Zugich et al., 2020). Since COVID-19 has been associated with coagulation (Zhang et al., 2020e), better condition of blood vessels in children could be a protection factor against the infection (Cyranoski, 2020). Nevertheless, age does not seem to affect the levels of LP components, in contrast with the circadian cycle, which plays a prominent role for MAp19, ficolin-3 and ficolin-1 levels (Troldborg et al., 2017). Pronounced age-related differences appear to happen only in the first year of life, with MASP-2 levels being considerably lower in preterm and term neonates, than in adults (Sallenbach et al., 2011).

COVID-19 infection is more common in males than in females (Rodriguez-Morales et al., 2020; Zhu et al., 2020; Teich et al., 2020), representing 58\% (Guan et al., 2020) to $67 \%$ of the cases in Chinese population (Chen et al., 2020a). Similarly, in a Brazilian study, 59.6\% were male (Teich et al., 2020). The hormone profile seems to be the key to these differences (Fairweather et al., 2008; Giefing-Kröll et al., 2015; Gaya da Costa et al., 2018). Hormone receptors bind to estrogens and androgens, which may impact the immune response (Fairweather et al., 2008). X chromosome inactivation (Schurz et al., 2019) and unequal expression of X-linked genes may also partly explain these differences (Ghorai and Ghosh, 2014; Klein and Flanagan, 2016). In general, the female immune response presents a better performance on vaccines and viral responses, at the cost of increased susceptibility to inflammatory and autoimmune diseases (Klein and Flanagan, 2016; Roved et al., 2017). In the context of the CS, high levels of serum MBL, ficolin-3, and MASP-1 and lower levels of MASP-2 (Troldborg et al., 2017; Gaya da Costa et al., 2018) were found in men compared to women, but MASP-3, MAp19 and MAp44 serum levels did not differ between sexes (Gaya da Costa et al., 2018) (Figure 5).

\section{Arterial hypertension and cardiovascular disease (CVD)}

Arterial hypertension is a multifactorial health problem, characterized by high blood pressure, which affects around 1.13 billion people (WHO, 2020b) and causes $13 \%$ of deaths worldwide (Chowdhury et al., 2020). It is a primary risk factor for premature cardiovascular diseases (CVD) and mortality. In Brazil, the prevalence was about $24.3 \%$ in 2017 , affecting $61 \%$ of adults above 65 years of age (Brasil - Ministério da Saúde, 2017). Age, sex, body mass, as well as environmental and genetic factors, contribute to rising blood pressure (Sabbatini and Kararigas, 2020).

Hypertension might be one of the most frequent comorbid diseases in patients with COVID-19 (Gao et al., 2020a; Guan et al., 2020; Hu et al., 2020). Gao et al. (2020a) showed that patients with hypertension have a two-fold increase in the mortality risk (adjusted hazard ratio $[\mathrm{HR}]=2.12,95 \% \mathrm{CI}=$ 1.17-3.82, $\mathrm{p}=0.013$ ) (Gao et al., 2020a).

Interestingly, SARS-CoV-2 enters human cells binding the Angiotensin-converting enzyme 2 (ACE2) (Zhou et al., 2020a). Hypertension is usually controlled with ACE inhibitors and angiotensin II type-I receptor blockers (ARBs), drugs that up-regulate ACE2, probably increasing opportunities 


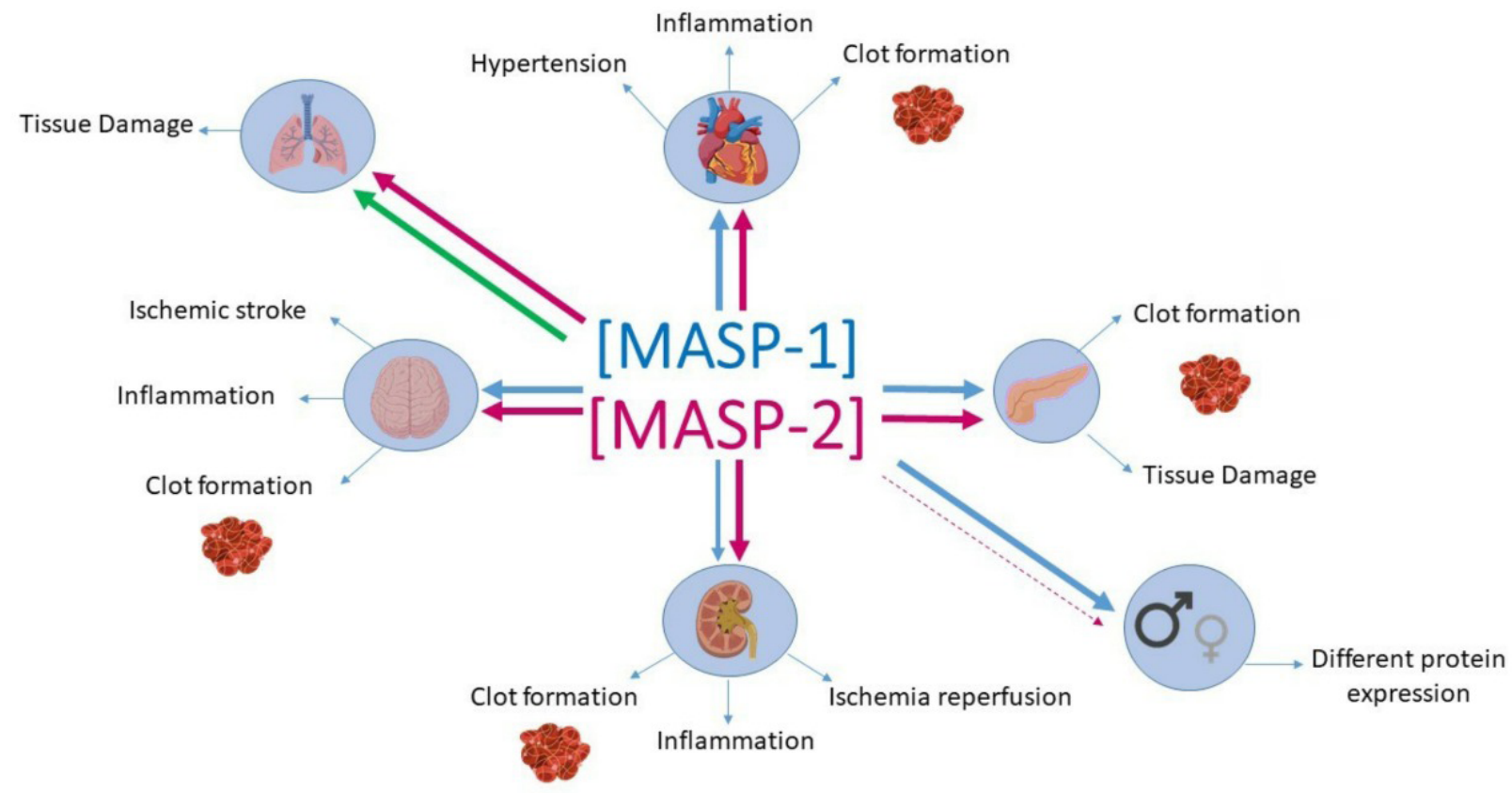

Figure 5 - Relationship between MASPs and COVID-19 comorbidities. Changes in MASPs levels have already been associated with COVID-19 risk factors, such as sex, diabetes, kidney, cardiovascular, cerebrovascular, and chronic obstructive pulmonary disease (COPD). Genetic polymorphisms in the $M A S P 1$ and MASP2 genes influence the expression levels of these proteins. COPD: high levels in plasma and increased detection in situ, after MASP-2 was associated with risk (thick pink arrow), MASP-1 has not yet been associated/investigated with COPD, but the evidence leads us to suggest that MASP-1 function is also a risk factor to these patients (green arrow). Arterial Hypertension and Cardiovascular Disease (CVD): high levels of MASP-1 and MASP-2 have been associated with risk. The participation of MASP-1 in the coagulation cascade contributes to the formation of clots, worsening CVD. Chronic kidney disease (CKD): high levels of MASP-2 are associated with ischemia-reperfusion injury (IR), and MASP-1 seems to play crucial roles in chronic kidney disease, as well as its associated symptoms and conditions, such as IR and kidney transplantation. Diabetes (DM): the natural hyperglycemic status, uncontrolled activation of the lectin pathway, with elevated MASPs concentration in DM patients, might partially explain why those individuals belong to the group with higher incidence and severity of COVID-19. Immunodeficiency and Immunosuppression: MASPs levels have been associated with the condition and outcome of HIV and immunosuppressed patients, who also can be considered more vulnerable to COVID-19 infection. Apparently, MASP-1 and MASP-2 levels were not associated with susceptibility to infections in patients with immunosuppression, for this reason, the topic is not represented in this figure. Cerebrovascular diseases: MASP-1 and MASP-2 show increased proteolytic activity in the ischemic stroke, inflammation, and clots formation. Sex: About two-thirds of COVID-19 patients are men, who also have a higher expression of MASP-1 and lower expression of MASP-2. The disseminated intravascular coagulation observed in severe COVID-19 are representations such as the formation of clots in the organs where this activity has already been observed. The thickness of the arrows indicates MASP expressions in each comorbidity. The blue arrows correspond to MASP-1 and the pink arrows to MASP-2. The dashed pink line means a decrease in MASP-2 expression.

for viral infection (Fang et al., 2020). Being expressed at blood vessels, ACE2 is part of the cardiovascular system. Thus, viral interaction can increase myocardial dysfunctions in cases with prior cardiovascular issues (Askin et al., 2020). Additionally, ACE2 is also expressed in the lung, intestinal epithelium, vascular endothelium, and kidneys, which is one of the causes of multiple organ failure in SARS-CoV-2 infection (Tikellis and Thomas, 2012; Zhang et al., 2020a). Higher levels of pro-inflammatory cytokines and coagulation activation factors indicate that inflammatory responses and the prothrombotic state are involved in COVID-19 symptoms (Chen et al., 2020a). As mentioned before, MASP-1 and MASP-2 play an important role in the coagulation system, activating several coagulation factors (Figure 3) (Kozarcanin et al., 2016). Indeed, MASP-1 levels are higher in myocardium infarction patients, as well as MASP-2 in coronary artery disease patients (Frauenknecht et al., 2013). MAp44 showed cardioprotective and antiatherothrombotic effects in two murine models, preserving cardiac function (Pavlov et al., 2012). Unexpectedly, in humans its levels correlated positively with cardiovascular risk factors, as dyslipidaemia, obesity and hypertension (Frauenknecht et al., 2013). Furthermore, Masp2 knockout mice presented smaller infarct injuries resulting from postischemic myocardial ischemia reperfusion (IR). Interestingly, the injuries in wild-type mice depend on Masp1, Masp-2, C2 and C3 (but not C4), and the injection of a murine-specific Masp-2 inhibitor greatly reduced the size of IR-induced gastrointestinal injuries (Schwaeble et al., 2011). Therefore, pharmacological inhibition of MASPs may reduce the risk to cardiovascular disease and improve the treatment of COVID-19 disease (Figure 5).

\section{Chronic kidney disease (CKD)}

Chronic kidney disease (CKD) is characterized as a reduction of glomerular filtration rate and/or increased urinary albumin excretion (Jha et al., 2013), and affects 10-15\% of adults worldwide (Zhang et al., 2020d). In Brazil, the prevalence of CKD is approximately 500 per million individuals (Jha et al., 2013). Diabetes and hypertension are the leading causes of CKD in many countries (Jha et al., 2013). However, genetic and environmental factors, the prevalence of infectious diseases, aging, and access to health care, can alter CKD epidemiology (De Nicola et al., 2015). Complications include cardiovascular events, kidney-disease progression, acute kidney injury, cognitive decline, and anaemia (Jha et al., 2013). 
Kidney disease is also a major complication of COVID-19 and a significant risk factor of death (Cheng et al., 2020b). It was previously reported that $6.7 \%$ of patients with SARSCoV-1 developed acute kidney injury (Chu et al., 2005). Furthermore, the incidence of in-hospital death was higher in patients with elevated baseline serum creatinine levels (33.7\%), in comparison to those with normal baseline serum creatinine levels (13.2\%) (Cheng et al., 2020b). Cheng et al. (2020b) investigated 701 patients with COVID-19 from Wuhan, China. Of this total, $2.0 \%$ reported chronic kidney disease as comorbidity, thus already presenting a proinflammatory state with functional defects in innate and adaptive immune cell populations (Betjes, 2013).

LP-mediated complement activation might have a negative impact in the pathophysiology of CKD, because of its involvement in IR, transplant immunity, and in the coagulation cascade (Takahashi et al., 2011). In these settings, the inactivation of MASP-1 and MASP-2 could prove beneficial. Asgari et al., (2014) indicated that MASP-2 presents a critical role for renal injury. In a Masp 2 knockout mouse transplant model, its absence protected the transplanted kidney from IR injury, with less C3 deposition, but in a C4-bypass independent mode (Asgari et al., 2014). Blocking Masp-2 reduces the harmful effects of proteinuria, by inactivating LP in proximal tubular cells of wild-type mice. This was as effective as in Masp2 knockout mice (Alghadban et al., 2019) (Figure 5). Yet low levels of MAp44 at the time of kidney transplantation were associated with increased mortality caused by infectious diseases in the recipients, after nearly 14 years of transplantation (Smedbråten et al., 2016). Therefore, MASP-1/-2 and MAp44 seem to play crucial roles in chronic kidney disease, as well as its associated symptoms and conditions, such as IR and kidney transplantation.

\section{Diabetes}

Long before the pandemic caused by SARS-CoV-2, the world has been experiencing the silent pandemic of diabetes mellitus (DM) (Santos et al., 2019; reviewed by Toniolo et al., 2019). In Brazil, the prevalence of the main risk factors for DM, elevated body mass index and obesity, are $55.7 \%$ and $19.8 \%$ respectively. Currently, DM occupies the third position as the most common factor leading to death. Its prevalence is about $8 \%$ in the Brazilian population (16.8 million people) and over 425 million people worldwide (Marinho et al., 2018; Saeedi et al., 2019). Along with a wide range of diseaseassociated complications, patients with DM present a variety of metabolic, vascular, and immune abnormalities which, combined with their inflammatory status, affect their response to pathogens (Mellbin et al., 2012; Kulcsar et al., 2019).

Previous viral epidemics, like SARS-CoV-1 and MERSCoV have shown that DM and uncontrolled glycaemia were among the predictive factors of severity and death in infected patients (Hussain et al., 2020). Some immune features observed in the pathogenesis of those viral infections in DM patients were related to dysfunction of several cellular immune components, but the humoral innate component, including the CS, have been poorly explored in DM patients, during those epidemics (Kulcsar et al., 2019; Singh et al., 2020). As observed in these respiratory viral infections, preexisting DM is associated with higher incidence, severity and mortality in COVID-19 patients (reviewed by Chen et al., 2020c; Wang et al., 2020b; Wu et al., 2020). Besides the common immune mechanisms, new predisposing factors might be responsible for the increased severity and even risk for SARS-CoV-2 infection in individuals with DM, as increased levels of IL6 , impaired T-cell function and higher expression of furin and ACE-2 (reviewed by Cristelo et al., 2020; Singh et al., 2020). This last receptor is probably up-regulated due to the common treatment of type 1 and type 2 diabetes with ACE inhibitors and ARBs, also used for hypertension (Fang et al., 2020). The dysfunction of complement activation in DM may have a major participation in inflammatory processes, endothelial damage, activation of blood coagulation and vascular complications, all common adverse outcomes of DM itself and of COVID-19 (reviewed by Ghosh et al., 2015; Huang et al., 2019).

The constant activation of the complement system, in the DM context, might be due to the production of advanced glycation end-products (AGE) and generation of neoepitopes by the hyperglycaemic environment and their interaction with MBL and MASPs. In fact, MBL binding to AGE induce conformational changes that activate MASP-1, and subsequently, MASP-2 (Jenny et al., 2015a; Pelletier et al., 2019). In prediabetes, type 1 and type 2 DM, plasma levels of MBL, MASP-1 and MASP-2 are elevated, and animal models have shown that MASP-1 levels rise just before the onset of DM symptoms (Jenny et al., 2015a; Krogh et al., 2017; Huang et al., 2019; Huth et al., 2019). Genetic association with protein levels was studied only in type 2 DM patients and relative to MASP1, of which five SNPs (rs874603, rs72549254, rs3774275, rs67143992, rs850312) were associated with plasma levels of MASP-1, MASP-3 and MAp44, but only MASP-1 levels were associated with the disease itself (however, the possible additive effect of the variants in a haplotype context, was not investigated) (Table 1). (Krogh et al., 2017). The link between hyperglycaemia and complement activation might also play an important role in the pathogenesis of SAR-CoV-2, since the control of blood glycemia seems to reduce death rates in DM infected patients (Hussain et al., 2020; reviewed by Cristelo et al., 2020; Fadini et al., 2020; Singh et al., 2020) (Figure 5).

\section{Chronic obstructive pulmonary disease (COPD)}

Chronic obstructive pulmonary disease (COPD) affects the airway and other pulmonary structures, resulting in airflow limitations caused, predominantly, by exposure to noxious particles or gases over a long period (reviewed by Decramer et al., 2012). The worldwide prevalence of COPD is estimated to be $4.76 \%$ (328 million cases) (Vos et al., 2012). In São Paulo, the most populated city of Brazil, this prevalence reaches $15.8 \%$ (Platino and Rosa, 2005).

The exacerbations of COPD have been frequently associated with viral infections (Retamales et al., 2001; reviewed by Leung et al., 2017; reviewed by Zwaans et al., 2020). Patients with pre-existing COPD infected by SARSCoV-2 are 4.4 times more likely to develop severe COVID-19, resulting in worse outcomes (Zhao et al., 2020) and higher mortality rates (Alqahtani et al., 2020). 
$M B L 2$ polymorphisms seem not to be associated with COPD per se. In the Danish population, genetic MBL deficiency was not considered a major risk factor for COPD (Dahl and Nordestgaard, 2009), and low MBL levels were not associated with COPD in Norwegian population (Eagan et al., 2010). Still, C3d deposition was detected in a set of 36 intensive care unit patients who died while on invasively mechanical ventilation, 12 of whom were diagnosed with ARDS (Beer et al., 2019). However, MBL levels were lower in bronchoalveolar lavage of COPD patients (Hodge et al., 2008). Furthermore, the deficiency-causing $M B L 2 * B$ allele (rs1800450) was associated with 4.9 times increased odds of hospital admission for infection-induced COPD exacerbation (Yang et al., 2003). This was confirmed in another setting, where $B / B$ homozygosity and the heterozygosity combined with the down-regulating promoter alleles $X A / B$ were not only associated with MBL deficiency, but also with frequent infection exacerbation in COPD, and worse outcomes (Lin et al., 2011). Furthermore, the LP seems to be activated in COPD, both in plasma and in situ. MASP-2 levels and LP activation were higher in plasma, and MASP-2 was also detected at higher amounts in the airways and lung parenchyma of COPD patients, compared with healthy individuals (Serban et al., 2019). Thus, the role played by MASPs and their polymorphisms in this disease deserves further investigation, especially regarding its effect on severe COVID-19 infection (Tables 1 and 2) (Figure 5).

\section{Secondary immunodeficiency and immunosuppression}

In former human coronavirus outbreaks, immunosuppressed individuals were not more prone to infections or severe complications. This scenario apparently changed with COVID-19 (D'Antiga, 2020). Among the secondary immunodeficiency causes enhancing COVID-19 severity, acquired immunodeficiency syndrome (AIDS) can be considered the most globally widespread. By the end of 2018, 37.9 million people were infected by the human immunodeficiency virus (HIV) globally, with 770,000 deaths in this same year (WHO, 2020c). Between 1980 and 2019, 966.058 AIDS cases were detected in Brazil (Brasil - Ministério da Saúde, 2019). AIDS is a condition caused by HIV infection, resulting in immunosuppression as a consequence of selective depletion of helper/inducer $\mathrm{T}$ lymphocytes that express the CD4 receptor (Fauci, 1988). Lopinavir-boosted ritonavir, antiretroviral treatment (ART) used for HIV infections, was tested against MERS-CoV and SARS-CoV-1 in the past, usually reducing viral loads (Chan et al., 2015; Sheahan et al., 2020). Following the hypothesis that HIV protease inhibitors might have activity against the coronavirus protease (pre-print Chang et al., 2020; Costanzo et al., 2020), lopinavir-boosted ritonavir and darunavir-boosted cobicistat, which are booted-protease inhibitors (ART), seemed to help the recovery of SARS-CoV-2 patients (Blanco et al., 2020). Conversely, these drugs did not shorten duration of SARS-CoV-2 viral shedding in patients with mild pneumonia (Cheng et al., 2020a). Later, in more extensive and robust tests, these ART were not found to be effective against SARS-CoV-2 in vivo (Cao et al., 2020; Jones et al., 2020).
The interaction between gp120 glycosylation sites present in the HIV envelope and MBL/MASP complexes have been established in vitro (Saifuddin et al., 2000; Hart et al., 2003). These observations lead to believe that MBL/ MASP complexes, and LP as a whole, act in early viral inhibition (reviewed by Ballegaard et al., 2014). However, in HIV pathogenesis, CS and its PRRs have two conflicting roles (Yu et al., 2010). In one hand, increased susceptibility to HIV infection was associated with low MASP-2 serum levels due to genetic polymorphisms, such as rs56392418 (Boldt et al., 2016a). (Table 2), and very low MBL levels were also observed in CDC stage II HIV infected patients (Prohászka et al., 1997). On the other hand, the complement element C3 binds to the virus, facilitating the interaction of HIV with CR3 and CR4 receptors of dendritic cells in vitro (Bajtay et al., 2004; Pruenster et al., 2005). Furthermore, MASP-2 lower levels/ structural deficiency associated with p.120G, p.126L, p.377A and p.439H (rs72550870, rs56392418, rs2273346 and rs12085877, respectively) presented a protective effect against AIDS, probably by suppressing inflammation (Boldt et al., 2016a) (Table 2).

Nevertheless, immunosuppressive medications for cancer therapy increase the risk of severe viral infections, due to is effects on humoral, cell-mediated immunity, and neutrophil function (Kaltsas and Sepkowitz, 2012). In cancer patients, these infections may also delay the treatment, causing unnecessary hospitalization (A1-Quteimat and Amer, 2020). Several reports indicate that cancer patients should be regarded as an extremely vulnerable group during the COVID-19 pandemic (Ueda et al., 2020; Gosain et al., 2020; Zhang et al., 2020c). In a nationwide cohort in China, COVID-19 patients with cancer showed a higher probability (39\%) to be admitted to intensive unit care and decease, if compared to COVID-19 patients without cancer (8\%) (Liang et al., 2020). Therefore, new guidelines to approach cancer care during the pandemic are being developed (Gosain et al., 2020). Whether or not immunosuppressive medication for cancer treatment should be interrupted during the pandemic, is still under debate (AlQuteimat and Amer, 2020; Ueda et al., 2020).

Patients with hematological malignancies have an impaired immune system not only due to the disease, but also because of its treatment. This scenario may be worsened by the presence of genetic variants lowering the efficacy of LP activation. In accordance with this, the MASP-2 deficiencycausing p.D120G polymorphism (rs72550870) was frequently found in lymphoma patients who experienced bacteremia during hospitalization, whereas fully-functional p.D371Y (rs12711521) was associated with decreased risk of diffuse large B-cell lymphoma (Table 2) (Hu et al., 2013; Świerzko et al., 2018). MASP-2 levels were similar between healthy controls and pre-treatment multiple myeloma and lymphoma patients (Świerzko et al., 2018). In another group of pediatric patients with hematologic malignancies, high MASP-2 levels were significantly associated with higher chance of event-free survival (Zehnder et al., 2009). Neutropenia occurs when patients with cancer have a temporary reduction in their neutrophil numbers caused by chemotherapy. Therefore, the risk of infection greatly increases in these patients 
(Patel and West, 2017). As expected, children going through chemotherapy and with MASP-2 deficiency have a two-fold increased risk of developing febrile neutropenia (Schlapbach et al., 2007). In conclusion, the characteristic "double-edge" association of MASP-2 (and probably also of MASP-1 and other LP components) with immunosuppression, infection and inflammation poises a difficult question regarding therapies directed to its inhibition, motivating further investigations in this field (Figure 5).

\section{Cerebrovascular diseases}

Cerebrovascular disease is a general term that includes different brain vascular disturbances, leading to the vast majority of deaths due to stroke (Truelsen et al., 2000). They have been reported as a comorbidity that increases the likelihood of a worse prognosis by up to 3.5 times in patients with COVID-19 (Aggarwal et al., 2020; Wang et al., 2020a). Worldwide, the mortality rate due to cerebrovascular diseases was 101 per 100,000 until 2015 (Wang et al., 2016). In Brazil, it is considered a neglected disease, with high prevalence and mortality (593,015 and 144,078 cases in 2015, respectively) (Lotufo et al., 2017). Indeed, the risk of dying prematurely due to stroke in Brazil is one of the highest in the world (Lotufo and Benseñor, 2009; Lotufo, 2015).

The involvement of CS in cerebrovascular disease has been reported by several studies, due to its close relationship with the coagulation cascade, which is suggested as a therapeutic target (Kramer et al., 2000; Mocco et al., 2006; Arumugam et al., 2009; Orsini et al., 2014; Larsen et al., 2018; Dobó et al., 2018; Ahmad et al., 2019; Ma et al., 2019). The LP probably plays a more important role than other complement pathways in cerebrovascular disease, possibly related to the role of MASP-1 in activating the coagulation cascade, leading to the formation of clots and/or recruiting leucocytes through pro-inflammatory factors, resulting in thrombosis and consequent tissue ischemia (Orsini et al., 2014; Dobó et al., 2018) (Figure 5).

Some independent studies (Cervera et al., 2010; Osthoff et al., 2011; Orsini et al., 2012; De La Rosa et al., 2014; Neglia et al., 2019, 2020) found a beneficial effect of MBL deficiency in stroke patients, improving prognosis and reducing $\mathrm{C} 3, \mathrm{C} 4$, and CRP levels, as well as the proinflammatory cytokine profile, neurological deficits and extent of brain lesions, although MBL may also be necessary at later stages, for the tissue recovery process (Ducruet et al., 2011). Besides that, ficolins also appear to play an important role in the severity of ischemia and in subarachnoid aneurysmal hemorrhage (SAH). Ficolin-2 and ficolin-3 occur at lower levels in ischemic stroke patients, due to their consumption in the acute phase of the pathology, and low ficolin-3 levels are associated with greater SAH severity (Füst et al., 2011; Orsini et al., 2014; Zanier et al., 2014). Orsini et al. (2016) demonstrated that MASP-2 contributes critically to tissue injury in an animal model of cerebral ischemia, probably due to an increase in C3 deposition in this area. Nevertheless, although MBL sufficient genotypes increased the odds for cerebral ischemia in humans, no protective association was found with the deficiencycausing MASP2 p.D120G polymorphism, probably due to its low frequency (no other $M A S P 2$ variant was investigated)
(Cervera et al., 2010). Double Masp1/Masp2 knock-out ischemic mice were also not protected (Orsini et al., 2016). In a study carried out in the Armenian population, it was found that patients with ischemic stroke had higher proteolytic activity of MASP-1 and MASP-2, than controls (5.8 and 3.7 times more, respectively) (Tsakanova et al., 2018). Taken together, the evidence warrants further investigation with MASP levels and polymorphisms (Tables 1 and 2) in the susceptibility to cerebral vascular ischemia, especially within the context of COVID-19 disease.

\section{Concluding remarks}

The pathophysiology of COVID-19 presents systemic hyper inflammation and hypercoagulation, affecting several organs (Berlin et al., 2020). Molecules that play a role in both inflammation and coagulation can be considered effective therapeutic targets for COVID-19. MASPs (mainly MASP-1) are key elements in the interaction between the complement system and blood coagulation. Increased levels of MASPs are associated with comorbidities of COVID-19 (CVD, CKD, diabetes, COPD and cerebrovascular diseases), and are associated with exacerbated inflammation and activity of the coagulation cascade. Furthermore, MASP-2 is suggested to interact with the $\mathrm{N}$ protein of SARS-COV-2, connecting the LP directly with viral recognition. Thus, the understanding of COVID-19 pathogenesis may benefit from studies of MASPs and their associations with risk factors, and of the role played by these molecules at the crossroad between the complement and coagulation systems. We propose that MASPs can be explored as biomarkers for disease progression, since the lectin pathway may be the first response against COVID-19. Furthermore, studies investigating MASP1 and $M A S P 2$ polymorphisms that may modulate the levels of MASPs in COVID-19 patients, can contribute to a greater understanding of the disease. Based on the promising results of Narsoplimab treatment, we suggest that pharmacological therapies aiming to inhibit MASPs would be effective in the treatment of COVID-19 and associated comorbidities.

\section{Acknowledgments}

We thank the Coordenação de Aperfeiçoamento de Pessoal de Nível Superior (CAPES/PROAP - Finance Code 001) for financial support and for the scholarships provided to G.C.K. (CAPES-40001016006P1), V.B-B. (CAPES-40001 016006P1), C.F.O-T. (40001016012P1), T.M.C. (CAPES40001016006P1) and N.M.A. We also thank the Conselho Nacional de Desenvolvimento Científico e Tecnológico (CNPq) for the scholarship provided to L.B.G (141955/2020$1)$, as well as for the research productivity scholarship for A.B.W.B (314288/2018-0). We thank the Genotype-Tissue Expression Project which was supported by the Common Fund of the Office of the Director of the National Institutes of Health, and by NCI, NHGRI, NHLBI, NIDA, NIMH, and NINDS. The data used for the analyses described in this paper were obtained from https://www.gtexportal.org.

\section{Conflicts of Interest}

Authors declare no conflict of interest. 


\section{Author Contributions}

ABWB and MHB contributed to the conception of the work. VBB, CFOT, TMC, GCK, LBG, NMA, MAGF wrote the manuscript. ABWB, MHB, VBB and CFOT revised the manuscript. All authors approved the final version of the work.

\section{References}

Aggarwal G, Lippi G and Michael Henry B (2020) Cerebrovascular disease is associated with an increased disease severity in patients with Coronavirus Disease 2019 (COVID-19): A pooled analysis of published literature. Int J Stroke 15:385-389.

Ahmad S, Bhatia K, Kindelin A and Ducruet AF (2019) The role of complement $\mathrm{C} 3$ a receptor in stroke. Neuromolecular Med 21:467-473.

Al-Quteimat OM and Amer AM (2020) The impact of the COVID-19 pandemic on cancer patients. Am J Clin Oncol 43:452-455.

Alghadban S, Kenawy HI, Dudler T, Schwaeble WJ and Brunskill NJ (2019) Absence of the lectin activation pathway of complement ameliorates proteinuria-induced renal injury. Front Immunol 10:2238.

Alqahtani JS, Oyelade T, Aldhahir AM, Alghamdi SM, Almehmadi M, Alqahtani AS, Quaderi S, Mandal S and Hurst JR (2020) Prevalence, severity and mortality associated with COPD and smoking in patients with COVID-19: A rapid systematic review and meta-analysis. PLoS One 15:e0233147.

Ammitzbøll CG, Steffensen R, Jørgen Nielsen H, Thiel S, Stengaard-Pedersen K, Bøgsted M and Jensenius JC (2013) Polymorphisms in the MASP1 gene are associated with serum levels of MASP-1, MASP-3, and MAp44. PLoS One 8:e73317.

Andrade FA, Lidani KCF, Catarino SJ and Messias-Reason IJ (2017) Serine proteases in the lectin pathway of the complement system. In: Chakraborti S and Dhalla NS (eds) Proteases in Physiology and Pathology. Springer, Singapore, pp 397-420.

Arumugam T V., Woodruff TM, Lathia JD, Selvaraj PK, Mattson MP and Taylor SM (2009) Neuroprotection in stroke by complement inhibition and immunoglobulin therapy. Neuroscience 158:1074-1089.

Asgari E, Farrar CA, Lynch N, Ali YM, Roscher S, Stover C, Zhou W, Schwaeble WJ and Sacks SH (2014) Mannan-binding lectinassociated serine protease 2 is critical for the development of renal ischemia reperfusion injury and mediates tissue injury in the absence of complement C4. FASEB J 28:3996-4003.

Askin L, Tanriverdi $O$ and Askin HS (2020) The effect of Coronavirus Disease 2019 on cardiovascular diseases. Arq Bras Cardiol 114:817-822.

Bajtay Z, Speth C, Erdei A and Dierich MP (2004) Cutting edge: productive HIV-1 infection of dendritic cells via complement receptor type 3 (CR3, CD11b/CD18). J Immunol 173:47754778.

Ballegaard V, Haugaard AK, Garred P, Nielsen SD and Munthe-Fog L (2014) The lectin pathway of complement: Advantage or disadvantage in HIV pathogenesis? Clin Immunol 154:13-25.

Beltrame MH, Boldt ABW, Catarino SJ, Mendes HC, Boschmann SE, Goeldner I and Messias-Reason I (2015) MBL-associated serine proteases (MASPs) and infectious diseases. Mol Immunol 67:85-100.

Berlin DA, Gulick RM and Martinez FJ (2020) Severe COVID-19. N Engl J Med 1-10.

Blanco JL, Ambrosioni J, Garcia F, Martínez E, Soriano A, Mallolas J and Miro JM (2020) COVID-19 in patients with HIV: clinical case series. Lancet HIV 7:e314-e316.

Boldt ABW, Goeldner I, Stahlke ERS, Thiel S, Jensenius JC and de Messias-Reason IJT (2013) Leprosy association with low MASP-2 levels generated by MASP2 haplotypes and polymorphisms flanking MAp19 exon 5. PLoS One 8:e69054.
Boldt ABW, Beltrame MH, Catarino SJ, Meissner CG, Tizzot R and Messias-Reason IJ (2016a) A dual role for Mannanbinding lectin-associated serine protease 2 (MASP-2) in HIV infection. Mol Immunol 78:48-56.

Boldt ABW, Boschmann SE, Catarino SJ, Andrade FA and de Messias-Reason IJ (2016b) MASP1 and MASP2. In: Choi $\mathrm{S}$ (ed) Encyclopedia of Signaling Molecules. Springer, New York. pp 1-18.

Bont CM, Boelens WC and Pruijn GJM (2019) NETosis, complement, and coagulation: a triangular relationship. Cell Mol Immunol 16:19-27.

Brian DA and Baric RS (2005) Coronavirus genome structure and replication. Curr Top Microbiol Immunol 287:1-30.

Cao B, Wang Y, Wen D, Liu W, Wang J, Fan G, Ruan L, Song B, Cai Y, Wei M, et al. (2020) A trial of lopinavir-ritonavir in adults hospitalized with severe Covid-19. N Engl J Med 382:1787-1799.

Cervera A, Planas AM, Justicia C, Urra X, Jensenius JC, Torres F, Lozano F and Chamorro A (2010) Genetically-defined deficiency of mannose-binding lectin is associated with protection after experimental stroke in mice and outcome in human stroke. PLoS One 5:e8433.

Chan JF-W, Yao Y, Yeung M-L, Deng W, Bao L, Jia L, Li F, Xiao C, Gao H, Yu P, et al. (2015) Treatment with lopinavir/ritonavir or interferon- $\beta 1 \mathrm{~b}$ improves outcome of MERS-CoV infection in a nonhuman primate model of common marmoset. J Infect Dis 212:1904-1913.

Chang Y, Tung Y, Lee K, Chen T, Hsiao Y, Chang C, Hsieh T, Su $\mathrm{C}$, Wang S, Yu J, et al. (2020) Potential therapeutic agents for COVID-19 based on the analysis of protease and RNA polymerase docking. Preprints:2020020242.

Chen G, Wu D, Guo W, Cao Y, Huang D, Wang H, Wang T, Zhang X, Chen H, Yu H, et al. (2020a) Clinical and immunological features of severe and moderate Coronavirus Disease 2019. J Clin Invest 130:2620-2629.

Chen N, Zhou M, Dong X, Qu J, Gong F, Han Y, Qiu Y, Wang J, Liu Y, Wei Y, et al. (2020b) Epidemiological and clinical characteristics of 99 cases of 2019 novel coronavirus pneumonia in Wuhan, China: a descriptive study. Lancet 395:507-513.

Chen Y, Gong X, Wang L and Guo J (2020c) Effects of hypertension, diabetes and coronary heart disease on COVID-19 diseases severity: a systematic review and meta-analysis. medRxiv 2020.03.25.20043133.

Cheng C-Y, Lee Y-L, Chen C-P, Lin Y-C, Liu C-E, Liao C-H and Cheng S-H (2020a) Lopinavir/ritonavir did not shorten the duration of SARS CoV-2 shedding in patients with mild pneumonia in Taiwan. J Microbiol Immunol Infect 53:488-492.

Cheng Y, Luo R, Wang K, Zhang M, Wang Z, Dong L, Li J, Yao Y, Ge S and Xu G (2020b) Kidney disease is associated with in-hospital death of patients with COVID-19. Kidney Int 97:829-838.

Chinn IK, Blackburn CC, Manley NR and Sempowski GD (2012) Changes in primary lymphoid organs with aging. Semin Immunol 24:309-320.

Chowdhury MZI, Rahman M, Akter T, Akhter T, Ahmed A, Shovon MA, Farhana Z, Chowdhury N and Turin TC (2020) Hypertension prevalence and its trend in Bangladesh: evidence from a systematic review and meta-analysis. Clin Hypertens 26:10.

Chu KH, Tsang WK, Tang CS, Lam MF, Lai FM, To KF, Fung KS, Tang HL, Yan WW, Chan HWH, et al. (2005) Acute renal impairment in coronavirus-associated severe acute respiratory syndrome. Kidney Int 67:698-705.

Connors JM and Levy JH (2020) COVID-19 and its implications for thrombosis and anticoagulation. Blood 135:2033-2040. 
Costanzo M, De Giglio MAR and Roviello GN (2020) SARS CoV-2: Recent reports on antiviral therapies based on lopinavir/ ritonavir, darunavir/umifenovir, hydroxychloroquine, remdesivir, favipiravir and other drugs for the treatment of the new coronavirus. Curr Med Chem 27:4536-4541.

Cristelo C, Azevedo C, Marques JM, Nunes R and Sarmento B (2020) SARS-CoV-2 and diabetes: New challenges for the disease. Diabetes Res Clin Pract 164:108228.

Cyranoski D (2020) Why children avoid the worst coronavirus complications might lie in their arteries. Nature 582:324-325.

D'Antiga L (2020) Coronaviruses and immunosuppressed patients: The facts during the third epidemic. Liver Transplant 26:832-834.

Dahl M and Nordestgaard BG (2009) Markers of early disease and prognosis in COPD. Int J COPD 4:157-167.

de Beer FM, Begieneman MP V., Roelofs JJTH, Horn J, Niessen HWM, Schultz MJ and Lagrand WK (2019) Pulmonary complement depositions in autopsy of critically ill patients have no relation with ARDS. Intensive Care Med Exp 7:1-11.

De La Rosa X, Cervera A, Kristoffersen AK, Valdés CP, Varma HM, Justicia C, Durduran T, Chamorro Á and Planas AM (2014) Mannose-binding lectin promotes local microvascular thrombosis after transient brain ischemia in mice. Stroke 45:1453-1459.

De Nicola L, Donfrancesco C, Minutolo R, Lo Noce C, Palmieri L, De Curtis A, Iacoviello L, Zoccali C, Gesualdo L, Conte G, et al. (2015) Prevalence and cardiovascular risk profile of chronic kidney disease in Italy: results of the 2008-12 National Health Examination Survey. Nephrol Dial Transplant 30:806-814.

Decramer M, Janssens W and Miravitlles M (2012) Chronic obstructive pulmonary disease. Lancet 379:1341-1351.

Degn SE, Hansen AG, Steffensen R, Jacobsen C, Jensenius JC and Thiel S (2009) MAp44, a human protein associated with pattern recognition molecules of the complement system and regulating the lectin pathway of complement activation. J Immunol 183:7371-7378.

Degn SE, Jensen L, Gál P, Dobó J, Holmvad SH, Jensenius JC and Thiel S (2010) Biological variations of MASP-3 and MAp44, two splice products of the MASP1 gene involved in regulation of the complement system. J Immunol Methods 361:37-50.

Degn SE and Thiel S (2013) Humoral pattern recognition and the complement system. Scand J Immunol 78:181-193.

Demopulos, G., Dudler, T., Nilsson, B., 2020. Compositions and methods of inhibiting MASP-2 for the treatment of various thrombotic diseases and disorders, https ://patents.google.com/ patent/WO2019246367A1/en?oq=WO2019246367.

Dobó J, Harmat V, Beinrohr L, Sebestyén E, Závodszky P and Gál P (2009) MASP-1, a promiscuous complement protease: structure of its catalytic region reveals the basis of its broad specificity. J Immunol 183:1207-1214.

Dobó J, Schroeder V, Jenny L, Cervenak L, Závodszky P and Gál P (2014) Multiple roles of complement MASP-1 at the interface of innate immune response and coagulation. Mol Immunol 61:69-78.

Dobó J, Szakács D, Oroszlán G, Kortvely E, Kiss B, Boros E, Szász R, Závodszky P, Gál P and Pál G (2016) MASP-3 is the exclusive pro-factor $\mathrm{D}$ activator in resting blood: The lectin and the alternative complement pathways are fundamentally linked. Sci Rep 6:1-12.

Dobó J, Kocsis A and Gál P (2018) Be on target: Strategies of targeting alternative and lectin pathway components in complementmediated diseases. Front Immunol 9:1851.

Ducruet AF, Sosunov SA, Zacharia BE, Gorski J, Yeh ML, DeRosa P, Cohen G, Gigante PR and Connolly ES (2011) The neuroprotective effect of genetic mannose-binding lectin deficiency is not sustained in the subacute phase of stroke. Transl Stroke Res 2:588-599.
Eagan TM, Aukrust P, Bakke PS, Damås JK, Skorge TD, Hardie JA, Ueland T and Mollnes TE (2010) Systemic mannose-binding lectin is not associated with chronic obstructive pulmonary disease. Respir Med 104:283-290.

Ehrengruber MU, Geiser T and Deranleau DA (1994) Activation of human neutrophils by C3a and C5A: Comparison of the effects on shape changes, chemotaxis, secretion, respiratory burst. FEBS Lett 346:181-184.

Elhadad S, Chapin J, Copertino D, Van Besien K, Ahamed J and Laurence J (2020) MASP2 levels are elevated in thrombotic microangiopathies: association with microvascular endothelial cell injury and suppression by anti-MASP2 antibody narso plimab. Clin Exp Immunol 5:1-9.

Endo Y, Takahashi M, Nakao M, Saiga H, Sekine H, Matsushita M, Nonaka M and Fujita T (1998) Two lineages of mannosebinding lectin-associated serine protease (MASP) in vertebrates. J Immunol 161:4924-30.

Eriksson O, Mohlin C, Nilsson B and Ekdahl KN (2019) The human platelet as an innate immune cell: Interactions between activated platelets and the complement system. Front Immunol 10:1590

Fadini GP, Morieri ML, Longato E and Avogaro A(2020) Prevalence and impact of diabetes among people infected with SARSCoV-2. J Endocrinol Invest 43:867-869.

Fairweather D, Frisancho-Kiss S and Rose NR (2008) Sex differences in autoimmune disease from a pathological perspective. Am J Pathol 173:600-609.

Fang L, Karakiulakis G and Roth M (2020) Are patients with hypertension and diabetes mellitus at increased risk for COVID-19 infection? Lancet Respir Med 8:e21.

Fauci AS (1988) The human immunodeficiency virus: Infectivity and mechanisms of pathogenesis. Science 239:617-622.

Fogarty H, Townsend L, Ni Cheallaigh C, Bergin C, Martin-Loeches I, Browne P, Bacon CL, Gaule R, Gillett A, Byrne M, et al. (2020) COVID19 coagulopathy in caucasian patients. Br J Haematol 189:1044-1049.

Frauenknecht V, Thiel S, Storm L, Meier N, Arnold M, Schmid JP, Saner H and Schroeder V (2013) Plasma levels of mannanbinding lectin (MBL)-associated serine proteases (MASPs) and MBL-associated protein in cardio- and cerebrovascular diseases. Clin Exp Immunol 173:112-120.

Fujita T (2002) Evolution of the lectin - Complement pathway and its role in innate immunity. Nat Rev Immunol 2:346-353.

Füst G, Munthe-Fog L, Illes Z, Széplaki G, Molnar T, Pusch G, Hirschberg K, Szegedi R, Széplaki Z, Prohászka Z, et al. (2011) Low ficolin-3 levels in early follow-up serum samples are associated with the severity and unfavorable outcome of acute ischemic stroke. J Neuroinflammation 8:185.

Gao C, Cai Y, Zhang K, Zhou L, Zhang Y, Zhang X, Li Q, Li W, Yang S, Zhao X, et al. (2020a) Association of hypertension and antihypertensive treatment with COVID-19 mortality: a retrospective observational study. Eur Heart J 41:2058-2066.

Gao T, Hu M, Zhang X, Li H, Zhu L, Liu H, Dong Q, Zhang Z, Wang Z, Hu Y, et al. (2020b) Highly pathogenic coronavirus N protein aggravates lung injury by MASP-2-mediated complement over-activation. medRxiv 2020.03.29.20041962.

Garred P, Genster N, Pilely K, Bayarri-Olmos R, Rosbjerg A, Ma YJ and Skjoedt MO (2016) A journey through the lectin pathway of complement-MBL and beyond. Immunol Rev 274:74-97.

Gaya da Costa M, Poppelaars F, van Kooten C, Mollnes TE, Tedesco F, Würzner R, Trouw LA, Truedsson L, Daha MR, Roos A, et al. (2018) Age and sex-associated changes of complement activity and complement levels in a healthy caucasian population. Front Immunol 9:2664.

Ghorai A and Ghosh U (2014) miRNA gene counts in chromosomes vary widely in a species and biogenesis of miRNA largely depends on transcription or post-transcriptional processing of coding genes. Front Genet 5:100. 
Ghosh P, Sahoo R, Vaidya A, Chorev M and Halperin JA (2015) Role of complement and complement regulatory proteins in the complications of diabetes. Endocr Rev 36:272-288.

Gialeli C, Gungor B and Blom AM (2018) Novel potential inhibitors of complement system and their roles in complement regulation and beyond. Mol Immunol 102:73-83.

Giefing-Kröll C, Berger P, Lepperdinger G and Grubeck-Loebenstein B (2015) How sex and age affect immune responses, susceptibility to infections, and response to vaccination. Aging Cell 14:309321.

Gosain R, Abdou Y, Singh A, Rana N, Puzanov I and Ernstoff MS (2020) COVID-19 and cancer: A comprehensive review. Curr Oncol Rep 22:53.

Gralinski LE, Sheahan TP, Morrison TE, Menachery VD, Jensen K, Leist SR, Whitmore A, Heise MT and Baric RS (2018) Complement activation contributes to severe acute respiratory syndrome coronavirus pathogenesis. MBio 9:e1753-18.

Guan W, Ni Z, Hu Y, Liang W, Ou C, He J, Liu L, Shan H, Lei C, Hui DSC, et al., (2020) Clinical characteristics of Coronavirus Disease 2019 in China. N Engl J Med 382:1708-1720.

Gulla KC, Gupta K, Krarup A, Gal P, Schwaeble WJ, Sim RB, O'Connor CD and Hajela K (2010) Activation of mannanbinding lectin-associated serine proteases leads to generation of a fibrin clot. Immunology 129:482-495.

Hansen S, Selman L, Palaniyar N, Ziegler K, Brandt J, Kliem A, Jonasson M, Skjoedt M-O, Nielsen $\mathrm{O}$, Hartshorn $\mathrm{K}$, et al. (2010) Collectin 11 (CL-11, CL-K1) Is a MASP-1/3-associated plasma collectin with microbial-binding activity. J Immunol 185:6096-6104.

Hart ML, Saifuddin M and Spear GT (2003) Glycosylation inhibitors and neuraminidase enhance human immunodeficiency virus type 1 binding and neutralization by mannose-binding lectin. J Gen Virol 84:353-360.

Hess K, Ajjan R, Phoenix F, Dobó J, Gál P and Schroeder V (2012) Effects of MASP-1 of the complement system on activation of coagulation factors and plasma clot formation. PLoS One 7:e35690

Hodge S, Hodge G, Jersmann H, Matthews G, Ahern J, Holmes M and Reynolds PN (2008) Azithromycin improves macrophage phagocytic function and expression of mannose receptor in chronic obstructive pulmonary disease. Am J Respir Crit Care Med 178:139-148.

Hoffmann M, Kleine-Weber H, Schroeder S, Krüger N, Herrler T, Erichsen S, Schiergens TS, Herrler G, Wu N-H, Nitsche A, et al. (2020) SARS-CoV-2 cell entry depends on ACE2 and TMPRSS2 and is blocked by a clinically proven protease inhibitor. Cell 181:271-280.e8.

Hu J, Zhang X, Zhang X, Zhao H, Lian J, Hao S, Jia H, Yang M, Lu Y, Xiang D, et al. (2020) COVID-19 patients with hypertension have more severity condition, and ACEI/ARB treatment have no infulence on the clinical severity and outcome. J Infect. 81:979-997.

Hu W, Bassig BA, Xu J, Zheng T, Zhang Y, Berndt SI, Holford TR, Hosgood HD, Leaderer B, Yeager M, et al. (2013) Polymorphisms in pattern-recognition genes in the innate immunity system and risk of non-Hodgkin lymphoma. Environ Mol Mutagen 54:72-77.

Huang Y, Xu J, Wu X, Chen X, Bai X, Zhuang Y, Fang J and Lin $X$ (2019) High expression of complement components in the kidneys of type 2 diabetic rats with diabetic nephropathy. Front Endocrinol 10:459.

Hui DS, I Azhar E, Madani TA, Ntoumi F, Kock R, Dar O, Ippolito G, Mchugh TD, Memish ZA, Drosten C, et al. (2020) The continuing 2019-nCoV epidemic threat of novel coronaviruses to global health - The latest 2019 novel coronavirus outbreak in Wuhan, China. Int J Infect Dis 91:264-266.
Hussain A, Bhowmik B and do Vale Moreira NC (2020) COVID-19 and diabetes: Knowledge in progress. Diabetes Res Clin Pract 162:108142.

Huth C, von Toerne C, Schederecker F, de las Heras Gala T, Herder C, Kronenberg F, Meisinger C, Rathmann W, Koenig W, Waldenberger M, et al. (2019) Protein markers and risk of type 2 diabetes and prediabetes: A targeted proteomics approach in the KORA F4/FF4 study. Eur J Epidemiol 34:409-422.

Ip WKE, Chan KH, Law HKW, Tso GHW, Kong EKP, Wong WHS, To YF, Yung RWH, Chow EY, Au KL, et al. (2005) Mannosebinding lectin in severe acute respiratory syndrome coronavirus infection. J Infect Dis 191:1697-1704.

Iwaki D, Kanno K, Takahashi M, Endo Y, Lynch NJ, Schwaeble WJ, Matsushita M, Okabe M and Fujita T (2006) Small mannosebinding lectin-associated protein plays a regulatory role in the lectin complement pathway. J Immunol 177:8626-8632.

Jenny L, Ajjan R, King R, Thiel S and Schroeder V (2015a) Plasma levels of mannan-binding lectin-associated serine proteases MASP-1 and MASP-2 are elevated in type 1 diabetes and correlate with glycaemic control. Clin Exp Immunol 180:227232.

Jenny L, Dobó J, Gál P and Schroeder V (2015b) MASP-1 of the complement system promotes clotting via prothrombin activation. Mol Immunol 65:398-405.

Jenny L, Dobó J, Gál P, Pál G, Lam WA and Schroeder V (2018) MASP-1 of the complement system enhances clot formation in a microvascular whole blood flow model. PLoS One 13: e0191292.

Jenny L, Noser D, Larsen JB, Dobó J, Gál P, Pál G and Schroeder V (2019) MASP-1 of the complement system alters fibrinolytic behaviour of blood clots. Mol Immunol 114:1-9.

Jha V, Garcia-Garcia G, Iseki K, Li Z, Naicker S, Plattner B, Saran R, Wang AY-M and Yang C-W (2013) Chronic kidney disease: Global dimension and perspectives. Lancet 382:260-272.

Jiang Y, Zhao G, Song N, Li P, Chen Y, Guo Y, Li J, Du L, Jiang S, Guo R, et al. (2018) Blockade of the C5a-C5aR axis alleviates lung damage in hDPP4-transgenic mice infected with MERSCoV article. Emerg Microbes Infect 7:77.

Jin Y, Yang H, Ji W, Wu W, Chen S, Zhang W and Duan G (2020) Virology, epidemiology, pathogenesis, and control of COVID-19. Viruses 12:372.

Jodele S and Köhl J (2020) Tackling COVID-19 infection through complement-targeted immunotherapy. Br J Pharmacol 1-17.

Jones R, Nelson M, Bracchi M, Asboe D and Boffito M (2020) COVID-19 in patients with HIV. Lancet HIV 7:e383.

Kajdácsi E, Jandrasics Z, Veszeli N, Makó V, Koncz A, Gulyás D, Köhalmi KV, Temesszentandrási G, Cervenak L, Gál P, et al. (2020) Patterns of C1-inhibitor/plasma serine protease complexes in healthy humans and in hereditary angioedema patients. Front Immunol 11:794.

Kaltsas A and Sepkowitz K (2012) Community acquired respiratory and gastrointestinal viral infections. Curr Opin Infect Dis 25:423-430.

Kjaer TR, Thiel S and Andersen GR (2013) Toward a structure-based comprehension of the lectin pathway of complement. Mol Immunol 56:413-422.

Klein SL and Flanagan KL (2016) Sex differences in immune responses. Nat Rev Immunol 16:626-638.

Kozarcanin H, Lood C, Munthe-Fog L, Sandholm K, Hamad OA, Bengtsson AA, Skjoedt M-O, Huber-Lang M, Garred P, Ekdahl $\mathrm{KN}$, et al. (2016) The lectin complement pathway serine proteases (MASPs) represent a possible crossroad between the coagulation and complement systems in thromboinflammation. J Thromb Haemost 14:531-545. 
Kramer J, Harcos P, Prohászka Z, Horváth L, Karádi I, Singh M, Császár A, Romics L and Füst G (2000) Frequencies of certain complement protein alleles and serum levels of anti-heatshock protein antibodies in cerebrovascular diseases. Stroke 31:2648-2652.

Krarup A, Wallis R, Presanis JS, Gál P and Sim RB (2007) Simultaneous activation of complement and coagulation by MBL-associated serine protease 2. PLoS One 2:e623.

Krarup A, Gulla KC, Gál P, Hajela K and Sim RB (2008) The action of MBL-associated serine protease 1 (MASP1) on factor XIII and fibrinogen. Biochim Biophys Acta - Proteins Proteomics 1784:1294-1300.

Krogh SS, Holt CB, Steffensen R, Funck KL, Høyem P, Laugesen E, Poulsen PL, Thiel S and Hansen TK (2017) Plasma levels of MASP-1, MASP-3 and MAp44 in patients with type 2 diabetes: influence of glycaemic control, body composition and polymorphisms in the MASP1 gene. Clin Exp Immunol 189:103-112.

Kulcsar KA, Coleman CM, Beck SE and Frieman MB (2019) Comorbid diabetes results in immune dysregulation and enhanced disease severity following MERS-CoV infection. JCI Insight 4:e131774.

Langereis JD, Van Den Broek B, Franssen S, Joosten I, Blijlevens NMA, De Jonge MI and Langemeijer S (2020) Eculizumab impairs Neisseria meningitidis serogroup B killing in whole blood despite $4 \mathrm{CMenB}$ vaccination of $\mathrm{PNH}$ patients. Blood Adv 4:3615-3620.

Larsen JB, Hvas CL and Hvas AM (2018) The lectin pathway in thrombotic conditions - A systematic review. Thromb Haemost 118:1141-1166.

Laurence J, Mulvey JJ, Seshadri M, Racanelli A, Harp J, Schenck EJ, Zappetti D, Horn EM and Magro CM (2020) Anti-complement C5 therapy with eculizumab in three cases of critical COVID-19. Clin Immunol 219:108555.

Leung JM, Tiew PY, Mac Aogáin M, Budden KF, Yong VFL, Thomas SS, Pethe K, Hansbro PM and Chotirmall SH (2017) The role of acute and chronic respiratory colonization and infections in the pathogenesis of COPD. Respirology 22:634-650.

Li G, Fan Y, Lai Y, Han T, Li Z, Zhou P, Pan P, Wang W, Hu D, Liu $\mathrm{X}$, et al. (2020) Coronavirus infections and immune responses. J Med Virol 92:424-432.

Liang W, Guan W, Chen R, Wang W, Li J, Xu K, Li C, Ai Q, Lu $\mathrm{W}$, Liang $\mathrm{H}$, et al. (2020) Cancer patients in SARS-CoV-2 infection: A nationwide analysis in China. Lancet Oncol 21:335-337.

Lin CL, Siu LK, Lin JC, Liu CY, Chian CF, Lee CN and Chang FY (2011) Mannose-binding lectin gene polymorphism contributes to recurrence of infective exacerbation in patients with COPD. Chest 139:43-51.

Liu B, Li M, Zhou Z, Guan X and Xiang Y (2020) Can we use interleukin-6 (IL-6) blockade for Coronavirus Disease 2019 (COVID-19)-induced cytokine release syndrome (CRS)? J Autoimmun 111:102452.

Liu JL, Cao C and Ma QJ (2009) Study on interaction between SARS-CoV N and MAP19. Xi bao yu fen zi mian yi xue za zhi= Chinese J Cell Mol Immunol 25:777.

Lo MW, Kemper C and Woodruff TM (2020) COVID-19: Complement, coagulation, and collateral damage. J Immunol 205:1488-1495.

Lotufo PA (2015) Acidente vascular cerebral permanece doença negligenciada no Brasil. Sao Paulo Med J 133:457-459.

Lotufo PA and Benseñor IM (2009) Stroke mortality in Brazil: One example of delayed epidemiological cardiovascular transition. Int J Stroke 4:40-41.

Lotufo PA, Goulart AC, De Azeredo Passos VM, Satake FM, de Souza MDFM, França EB, Ribeiro ALP and Bensenõr IJM (2017) Cerebrovascular disease in Brazil from 1990 to 2015: Global Burden of Disease 2015. Rev Bras Epidemiol 20:129-141.
Lu X, Zhang L, Du H, Zhang J, Li YY, Qu J, Zhang W, Wang Y, Bao S, Li Y, et al. (2020) SARS-CoV-2 infection in children. N Engl J Med 382:1663-1665.

Ma Y, Liu Y, Zhang Z and Yang GY (2019) Significance of complement system in ischemic stroke: A comprehensive review. Aging Dis 10:429-462.

Magro C, Mulvey JJ, Berlin D, Nuovo G, Salvatore S, Harp J, BaxterStoltzfus A and Laurence J (2020) Complement associated microvascular injury and thrombosis in the pathogenesis of severe COVID-19 infection: A report of five cases. Transl Res 220:1-13.

Malik YA (2020) Properties of coronavirus and SARS-CoV-2. Malays J Pathol 42:3-11.

Marcos-Jimenez A, Sanchez-Alonso S, Alcaraz-Serna A, Esparcia L, Lopez-Sanz C, Sampedro-Nunez M, Mateu-Albero T, SánchezCerrillo I, Martínez-Fleta P, Gabrie L, et al. (2020). Deregulated cellular circuits driving immunoglobulins and complement consumption associate with the severity of COVID-19. Eur J Immunol 10.1002/eji.202048858

Marinho F, de Azeredo Passos VM, Carvalho Malta D, Barboza França E, Abreu DMX, Araújo VEM, Bustamante-Teixeira MT, Camargos PAM, da Cunha CC, Duncan BB, et al. (2018) Burden of disease in Brazil, 1990-2016: A systematic subnational analysis for the Global Burden of Disease Study 2016. Lancet 392:760-775

Mastellos DC, Pires da Silva BGP, Fonseca BAL, Fonseca NP, Auxiliadora-Martins M, Mastaglio S, Ruggeri A, Sironi M, Radermacher P, Chrysanthopoulou A, et al. (2020) Complement C3 vs C5 inhibition in severe COVID-19: Early clinical findings reveal differential biological efficacy. Clin Immunol 220:108598.

Matricardi PM, Dal Negro RW and Nisini R (2020) The first, holistic immunological model of COVID-19: Implications for prevention, diagnosis, and public health measures. Pediatr Allergy Immunol 31:454-470.

Megyeri M, Mako V, Beinrohr L, Doleschall Z, Prohaszka Z, Cervenak L, Zavodszky P and Gal P (2009a) Complement protease MASP-1 activates human endothelial cells: PAR4 activation is a link between complement and endothelial function. $\mathrm{J}$ Immunol 183:3409-3416.

Megyeri M, Makó V, Beinrohr L, Doleschall Z, Prohászka Z, Cervenak L, Závodszky P and Gál P (2009b) Complement protease MASP-1 activates human endothelial cells: PAR4 activation is a link between complement and endothelial function. J Immunol 183:3409-3416.

Megyeri M, Harmat V, Major B, Végh Á, Balczer J, Héja D, Szilágyi K, Datz D, Pál G, Závodszky P, et al. (2013) Quantitative characterization of the activation steps of mannan-binding lectin (MBL)-associated serine proteases (MASPs) points to the central role of MASP-1 in the initiation of the complement lectin pathway. J Biol Chem 288:8922-8934.

Mellbin LG, Bjerre M, Thiel S and Hansen TK (2012) Complement activation and prognosis in patients with type 2 diabetes and myocardial infarction: A report from the DIGAMI 2 trial. Diabetes Care 35:911-917.

Mizumoto K, Kagaya K, Zarebski A and Chowell G (2020) Estimating the asymptomatic proportion of Coronavirus Disease 2019 (COVID-19) cases on board the Diamond Princess cruise ship, Yokohama, Japan, 2020. Euro Surveill 25:2000180.

Mocco JJ, Sughrue ME, Ducruet AF, Komotar RJ, Sosunov SA and Connolly ES (2006) The complement system: A potential target for stroke therapy. Adv Exp Med Biol 586:189-201.

Neglia L, Fumagalli S, Orsini F, Zanetti A, Perego C and De Simoni M-G (2019) Mannose-binding lectin has a direct deleterious effect on ischemic brain microvascular endothelial cells. J Cereb Blood Flow Metab 40:1608-1620. 
Neglia L, Oggioni M, Mercurio D, De Simoni MG and Fumagalli S (2020) Specific contribution of mannose-binding lectin murine isoforms to brain ischemia/reperfusion injury. Cell Mol Immunol 17:218-226.

Nikolich-Zugich J, Knox KS, Rios CT, Natt B, Bhattacharya D and Fain MJ (2020) SARS-CoV-2 and COVID-19 in older adults: what we may expect regarding pathogenesis, immune responses, and outcomes. GeroScience 42:505-514.

Nishimura JI, Yamamoto M, Hayashi S, Ohyashiki K, Ando K, Brodsky AL, Noji H, Kitamura K, Eto T, Takahashi T, et al. (2014) Genetic variants in C5 and poor response to eculizumab. N Engl J Med 370:632-639.

Omeros Corporation (2013a). Included in narsoplimab Biologics License Application to the U.S. Food and Drug Administration. Technical report number 13-021 inhibition of microvascular thrombosis by OMS721.

Omeros Corporation (2013b). Included in narsoplimab Biologics License Application to the U.S. Food and Drug Administration. Technical report number 13-022 evaluation of the effect of MASP-2 blockade on mouse hemostasis measured by the tail bleeding assay.

Omeros Corporation (2019). Clinical study report for study OMS721-NHV-001 "Phase 1 sequential dose-escalation study to evaluate the safety, tolerability, pharmacokinetics, and pharmacodynamics of single-dose administration of OMS721 in healthy male subjects".

Orsini F, Chrysanthou E, Dudler T, Cummings WJ, Takahashi M, Fujita T, Demopulos G, De Simoni MG and Schwaeble W (2016) Mannan binding lectin-associated serine protease-2 (MASP-2) critically contributes to post-ischemic brain injury independent of MASP-1. J Neuroinflammation 13:213.

Orsini F, De Blasio D, Zangari R, Zanier ER and De Simoni MG (2014) Versatility of the complement system in neuroinflammation, neurodegeneration and brain homeostasis. Front Cell Neurosci 8:830.

Orsini F, Villa P, Parrella S, Zangari R, Zanier ER, Gesuete R, Stravalaci M, Fumagalli S, Ottria R, Reina JJ, et al. (2012) Targeting mannose-binding lectin confers long-lasting protection with a surprisingly wide therapeutic window in cerebral ischemia. Circulation 126:1484-1494.

Osthoff M, Katan M, Fluri F, Schuetz P, Bingisser R, Kappos L, Steck AJ, Engelter ST, Mueller B, Christ-Crain M, et al. (2011) Mannose-binding lectin deficiency is associated with smaller infarction size and favorable outcome in ischemic stroke patients. PLoS One 6:e21338.

Paréj K, Dobó J, Závodszky P and Gál P (2013) The control of the complement lectin pathway activation revisited: Both $\mathrm{C} 1$ inhibitor and antithrombin are likely physiological inhibitors, while $\alpha 2$-macroglobulin is not. Mol Immunol 54:415-422.

Patel K and West HJ (2017) Febrile neutropenia. JAMA Oncol 3:1751.

Pavlov VI, Skjoedt M-O, Siow Tan Y, Rosbjerg A, Garred P and Stahl GL (2012) Endogenous and natural complement inhibitor attenuates myocardial injury and arterial thrombogenesis. Circulation 126:2227-2235.

Pelletier K, Bonnefoy A, Chapdelaine H, Pichette V, Lejars M, Madore F, Brachemi S and Troyanov S (2019) Clinical value of complement activation biomarkers in overt diabetic nephropathy. Kidney Int Reports 4:797-805.

Platino E and Rosa F (2005) Prevalence of chronic obstructive pulmonary disease and associated factors: The PLATINO Study in São Paulo, Brazil prevalência de doença pulmonar obstrutiva crônica e fatores associados Cad Saúde Pública 21:1565-1573.
Prendergast AJ, Klenerman P and Goulder PJR (2012) The impact of differential antiviral immunity in children and adults. Nat Rev Immunol 12:636-648.

Prohászka Z, Thiel S, Ujhelyi E, Szlávik J, Bánhegyi D and Füst $\mathrm{G}$ (1997) Mannan-binding lectin serum concentrations in HIV-infected patients are influenced by the stage of disease. Immunol Lett 58:171-175.

Prompetchara E, Ketloy C and Palaga T (2020) Immune responses in COVID-19 and potential vaccines: Lessons learned from SARS and MERS epidemic. Asian Pacific J Allergy Immunol 38:1-9.

Pruenster M, Wilflingseder D, Bánki Z, Ammann CG, Muellauer B, Meyer M, Speth C, Dierich MP and Stoiber H (2005) C-type lectin-independent interaction of complement opsonized HIV with monocyte-derived dendritic cells. Eur J Immunol 35:2691-2698.

Rabaan AA, Al-Ahmed SH, Haque S, Sah R, Tiwari R, Malik YS, Dhama K, Yatoo MI, Bonilla-Aldana DK and RodriguezMorales AJ (2020) SARS-CoV-2, SARS-CoV, and MERSCOV: A comparative overview. Le Infez Med 28:174-184.

Rambaldi A, Gritti G, Micò MC, Frigeni M, Borleri G, Salvi A, Landi F, Pavoni C, Sonzogni A, Gianatti A, et al. (2020) Endothelial injury and thrombotic microangiopathy in COVID-19: Treatment with the lectin-pathway inhibitor narsoplimab. Immunobiology 225:152001.

Ranucci M, Ballotta A, Di Dedda U, Bayshnikova E, Dei Poli M, Resta M, Falco M, Albano G and Menicanti L (2020) The procoagulant pattern of patients with COVID-19 acute respiratory distress syndrome. J Thromb Haemost 18:17471751.

Retamales I, Elliott WM, Meshi B, Coxson HO, Pare PD, Sciurba FC, Rogers RM, Hayashi S and Hogg JC (2001) Amplification of inflammation in emphysema and its association with latent adenoviral infection. Am J Respir Crit Care Med 164:469-473.

Ricklin D, Reis ES and Lambris JD (2016) Complement in disease: A defence system turning offensive. Nat Rev Nephrol 12:383401.

Risitano AM, Mastellos DC, Huber-Lang M, Yancopoulou D, Garlanda C, Ciceri F and Lambris JD (2020) Complement as a target in COVID-19? Nat Rev Immunol. 20:343-344.

Rodriguez-Morales AJ, Cardona-Ospina JA, Gutiérrez-Ocampo E, Villamizar-Peña R, Holguin-Rivera Y, Escalera-Antezana JP, Alvarado-Arnez LE, Bonilla-Aldana DK, Franco-Paredes C, Henao-Martinez AF, et al. (2020) Clinical, laboratory and imaging features of COVID-19: A systematic review and meta-analysis. Travel Med Infect Dis 34:101623.

Rooryck C, Diaz-Font A, Osborn DPS, Chabchoub E, HernandezHernandez V, Shamseldin H, Kenny J, Waters A, Jenkins D, Kaissi A Al, et al. (2011) Mutations in lectin complement pathway genes COLEC11 and MASP1 cause 3MC syndrome. Nat Genet 43:197-203.

Roved J, Westerdahl H and Hasselquist D (2017) Sex differences in immune responses: Hormonal effects, antagonistic selection, and evolutionary consequences. Horm Behav 88:95-105.

Russell TW, Hellewell J, Jarvis CI, Zandvoort K Van, Abbott S, Ratnayake R, Flasche S, Eggo RM, Edmunds WJ and Kucharski AJ (2020) Estimating the infection and case fatality ratio for Coronavirus Disease (COVID-19) using age-adjusted data from the outbreak on the Diamond Princess cruise ship, February 2020. Eurosurveillance 25:6-10.

Sabbatini AR and Kararigas G (2020) Estrogen-related mechanisms in sex differences of hypertension and target organ damage. Biol Sex Differ 11:31.

Saeedi P, Petersohn I, Salpea P, Malanda B, Karuranga S, Unwin $\mathrm{N}$, Colagiuri S, Guariguata L, Motala AA, Ogurtsova K, et al. (2019) Global and regional diabetes prevalence estimates 
for 2019 and projections for 2030 and 2045: Results from the International Diabetes Federation Diabetes Atlas, 9th edition. Diabetes Res Clin Pract 157:107843.

Saifuddin M, Hart ML, Gewurz H, Zhang Y and Spear GT (2000) Interaction of mannose-binding lectin with primary isolates of human immunodeficiency virus type 1. J Gen Virol 81:949955.

Sallenbach S, Thiel S, Aebi C, Otth M, Bigler S, Jensenius JC, Schlapbach LJ and Ammann RA (2011) Serum concentrations of lectin-pathway components in healthy neonates, children and adults: Mannan-binding lectin (MBL), M-, L-, and $\mathrm{H}$-ficolin, and MBL-associated serine protease-2 (MASP-2). Pediatr Allergy Immunol 22:424-430.

Santos J, Vieira L, Pionorio M and Silva I (2019) Diabetes mellitus in Brazil: Risk factors, classification and complications. Int J Med Rev Case Reports 3:1.

Schlapbach LJ, Aebi C, Otth M, Leibundgut K, Hirt A and Ammann RA (2007) Deficiency of mannose-binding lectin-associated serine protease- 2 associated with increased risk of fever and neutropenia in pediatric cancer patients. Pediatr Infect Dis J 26:989-994.

Schurz H, Salie M, Tromp G, Hoal EG, Kinnear CJ and Möller M (2019) The X chromosome and sex-specific effects in infectious disease susceptibility. Hum Genomics 13:2.

Schwaeble WJ, Lynch NJ, Clark JE, Marber M, Samani NJ, Ali YM, Dudler T, Parent B, Lhotta K, Wallis R, et al. (2011) Targeting of mannan-binding lectin-associated serine protease- 2 confers protection from myocardial and gastrointestinal ischemia/ reperfusion injury. Proc Natl Acad Sci 108:7523-7528.

Serban KA, Mikosz A, Strange C, Janciauskiene SM, Stolk J, Jonigk D, Sandhaus RA and Petrache I (2019) Lectin complement pathway in emphysema. Am J Respir Crit Care Med 199:659661.

Shang J, Wan Y, Luo C, Ye G, Geng Q, Auerbach A and Li F (2020) Cell entry mechanisms of SARS-CoV-2. Proc Natl Acad Sci U S A 117:202003138.

Shaw AC, Goldstein DR and Montgomery RR (2013) Age-dependent dysregulation of innate immunity. Nat Rev Immunol 13:875887.

Sheahan TP, Sims AC, Leist SR, Schäfer A, Won J, Brown AJ, Montgomery SA, Hogg A, Babusis D, Clarke MO, et al. (2020) Comparative therapeutic efficacy of remdesivir and combination lopinavir, ritonavir, and interferon beta against MERS-CoV. Nat Commun 11:222.

Singh AK, Gupta R, Ghosh A and Misra A (2020) Diabetes in COVID-19: Prevalence, pathophysiology, prognosis and practical considerations. Diabetes Metab Syndr Clin Res Rev 14:303-310.

Skendros P, Mitsios A, Chrysanthopoulou A, Mastellos DC, Metallidis S, Rafailidis P, Ntinopoulou M, Sertaridou E, Tsironidou $\mathrm{V}$, Tsigalou C, et al. (2020) Complement and tissue factorenriched neutrophil extracellular traps are key drivers in COVID-19 immunothrombosis. J Clin Invest 130:6151-6157.

Smedbråten J, Mjøen G, Hartmann A, Åsberg A, Rollag H, Mollnes TE, Sandvik L, Fagerland MW, Thiel S and Sagedal S (2016) Low level of MAp44, an inhibitor of the lectin complement pathway, and long-term graft and patient survival; a cohort study of 382 kidney recipients. BMC Nephrol 17:148.

Sørensen R, Thiel S and Jensenius JC (2005) Mannan-bindinglectin-associated serine proteases, characteristics and disease associations. Springer Semin Immunopathol 27:299-319.

Stahel PF and Barnum SR (2020) Complement inhibition in Coronavirus Disease (COVID)-19: A neglected therapeutic option. Front Immunol 11:1661.
Stengaard-Pedersen K, Thiel S, Gadjeva M, Møller-Kristensen M, Sørensen R, Jensen LT, Sjöholm AG, Fugger L and Jensenius JC (2003) Inherited deficiency of mannan-binding lectinassociated serine protease 2. N Engl J Med 349:554-560.

Stover CM, Thiel S, Thelen M, Lynch NJ, Vorup-Jensen T, Jensenius JC and Schwaeble WJ (1999) Two constituents of the initiation complex of the mannan-binding lectin activation pathway of complement are encoded by a single structural gene. J Immunol 162:3481-90.

Świerzko AS, Michalski M, Sokołowska A, Nowicki M, Eppa Ł, Szala-Poździej A, Mitrus I, Szmigielska-Kapłon A, Sobczyk-Kruszelnicka M, Michalak K, et al. (2018) The role of complement activating collectins and associated serine proteases in patients with hematological malignancies, receiving high-dose chemotherapy, and autologous hematopoietic stem cell transplantations (Auto-HSCT). Front Immunol 9:2153.

Świerzko AS and Cedzyński M. (2020) The influence of the lectin pathway of complement activation on infections of the respiratory system. Front Immunol 11:585243.

Takahashi K, Chang W-C, Takahashi M, Pavlov V, Ishida Y, La Bonte L, Shi L, Fujita T, Stahl GL and Van Cott EM (2011) Mannose-binding lectin and its associated proteases (MASPs) mediate coagulation and its deficiency is a risk factor in developing complications from infection, including disseminated intravascular coagulation. Immunobiology 216:96-102.

Tanaka T, Narazaki M and Kishimoto T (2014) IL-6 in Inflammation, immunity, and disease. Cold Spring Harb Perspect Biol 6:a016295-a016295.

Tang N, Bai H, Chen X, Gong J, Li D and Sun Z (2020a) Anticoagulant treatment is associated with decreased mortality in severe Coronavirus Disease 2019 patients with coagulopathy. J Thromb Haemost 18:1094-1099.

Tang N, Li D, Wang X and Sun Z (2020b) Abnormal coagulation parameters are associated with poor prognosis in patients with novel coronavirus pneumonia. J Thromb Haemost 18:844-847.

Tay MZ, Poh CM, Rénia L, MacAry PA and Ng LFP (2020) The trinity of COVID-19: immunity, inflammation and intervention. Nat Rev Immunol 20:363-374.

Teich VD, Klajner S, Almeida FAS de, Dantas ACB, La Selva CR, Torritesi MG, Canero TR, Berwanger O, Rizzo LV, Reis EP, et al. (2020) Características epidemiológicas e clínicas dos pacientes com COVID-19 no Brasil. Einstein (São Paulo) 18:eAO6022.

Thiel S, Steffensen R, Christensen IJ, Ip WK, Lau YL, Reason IJM, Eiberg H, Gadjeva M, Ruseva M and Jensenius JC (2007) Deficiency of mannan-binding lectin associated serine protease-2 due to missense polymorphisms. Genes Immun 8:154-163.

Thiel S, Kolev M, Degn S, Steffensen R, Hansen AG, Ruseva M and Jensenius JC (2009) Polymorphisms in mannan-binding lectin (MBL)-associated serine protease 2 affect stability, binding to MBL, and enzymatic activity. J Immunol 182:2939-2947.

Thomson TM, Toscano E, Casis E and Paciucci R (2020) C1 esterase inhibitor and the contact system in COVID-19. Br J Haematol 190:520-524.

Tikellis C and Thomas MC (2012) Angiotensin-converting enzyme 2 (ACE2) is a key modulator of the renin angiotensin system in health and disease. Int J Pept 2012: 256294.

Toniolo A, Cassani G, Puggioni A, Rossi A, Colombo A, Onodera T and Ferrannini E (2019) The diabetes pandemic and associated infections. Rev Med Microbiol 30:1-17.

Troldborg A, Hansen A, Hansen SWK, Jensenius JC, StengaardPedersen K and Thiel S (2017) Lectin complement pathway proteins in healthy individuals. Clin Exp Immunol 188:138-147. 
Truelsen T, Begg S and Mathers C (2000) The global burden of cerebrovascular disease. In: World Health Organization. Global Burden of Disease. World Health Organization, Geneva. pp $1-67$.

Tsakanova G, Stepanyan A, Nahapetyan K, Sim RB, Arakelyan A and Boyajyan A (2018) Serine proteases of the complement lectin pathway and their genetic variations in ischaemic stroke. J Clin Pathol 71:141-147.

Ueda M, Martins R, Hendrie PC, McDonnell T, Crews JR, Wong TL, McCreery B, Jagels B, Crane A, Byrd DR, et al. (2020) Managing cancer care during the COVID-19 pandemic: Agility and collaboration toward a common goal. J Natl Compr Cancer Netw 18:366-369.

Valencia DN (2020) Brief Review on COVID-19: The 2020 pandemic caused by SARS-CoV-2. Cureus 12:e7386.

Vallejo AN (2006) Age-dependent alterations of the T cell repertoire and functional diversity of $\mathrm{T}$ cells of the aged. Immunol Res 36:221-228.

Vos T, Flaxman AD, Naghavi M, Lozano R, Michaud C, Ezzati M, Shibuya K, Salomon JA, Abdalla S, Aboyans V, et al. (2012) Years lived with disability (YLDs) for 1160 sequelae of 289 diseases and injuries 1990-2010: A systematic analysis for the Global Burden of Disease Study 2010. Lancet 380:2163-2196.

Wang B, Li R, Lu Z and Huang Y (2020a) Does comorbidity increase the risk of patients with Covid-19: Evidence from metaanalysis. Aging (Albany NY) 12:6049-6057.

Wang D, Hu B, Hu C, Zhu F, Liu X, Zhang J, Wang B, Xiang H, Cheng Z, Xiong Y, et al. (2020b) Clinical characteristics of 138 hospitalized patients with 2019 novel coronavirus-infected pneumonia in Wuhan, China. JAMA 323:1061.

Wang H, Naghavi M, Allen C, Barber RM, Bhutta ZA, Carter A, Casey DC, Charlson FJ, Chen AZ, Coates MM, et al. (2016) Global, regional, and national life expectancy, all-cause mortality, and cause-specific mortality for 249 causes of death, 1980-2015: A systematic analysis for the Global Burden of Disease Study 2015. Lancet 388:1459-1544.

Wang Y, Yan J, Shi Y, Li P, Liu C, Ma Q, Yang R, Wang X, Zhu L, Yang $X$, et al. (2009) Lack of association between polymorphisms of MASP2 and susceptibility to SARS coronavirus infection. BMC Infect Dis 9:51.

Weinschutz Mendes H, Boldt ABW, von Rosen Seeling Stahlke E, Jensenius JC, Thiel S and Messias-Reason IJT (2020) Adding MASP1 to the lectin pathway-Leprosy association puzzle: Hints from gene polymorphisms and protein levels. PLoS Negl Trop Dis 14:e0007534.

Weng N (2006) Aging of the immune system: How much can the adaptive immune system adapt? Immunity 24:495-499.

Wölfel R, Corman VM, Guggemos W, Seilmaier M, Zange S, Müller MA, Niemeyer D, Jones TC, Vollmar P, Rothe C et al. (2020) Virological assessment of hospitalized patients with COVID-2019. Nature 581:465-469.

Wu C, Chen X, Cai Y, Xia J, Zhou X, Xu S, Huang H, Zhang L, Zhou X, Du C, et al. (2020) Risk factors associated with acute respiratory distress syndrome and death in patients with Coronavirus Disease 2019 pneumonia in Wuhan, China. JAMA Intern Med 1-10.

Yang IA, Seeney SL, Wolter JM, Anders EM, McCormack JG, Tunnicliffe AM, Rabnott GC, Shaw JG, Dent AG, Kim ST et al. (2003) Mannose-binding lectin gene polymorphism predicts hospital admissions for COPD infections. Genes Immun 4:269-274.

Yang Y, Peng F, Wang R, Guan K, Jiang T, Xu G, Sun J and Chang C (2020) The deadly coronaviruses: The 2003 SARS pandemic and the 2020 novel coronavirus epidemic in China. J Autoimmun 109:102434.

Ye Q, Wang B and Mao J (2020) The pathogenesis and treatment of the 'Cytokine Storm' in COVID-19. J Infect 80:607-613.

Yu Q, Yu R and Qin X (2010) The good and evil of complement activation in HIV-1 infection. Cell Mol Immunol 7:334-340.

Yuen J, Pluthero FG, Douda DN, Riedl M, Cherry A, Ulanova M, Kahr WHA, Palaniyar N and Licht C (2016) NETosing neutrophils activate complement both on their own NETs and bacteria via alternative and non-alternative pathways. Front Immunol 7:137.

Zanier ER, Zangari R, Munthe-Fog L, Hein E, Zoerle T, Conte V, Orsini F, Tettamanti M, Stocchetti N, Garred P, et al. (2014) Ficolin-3-mediated lectin complement pathway activation in patients with subarachnoid hemorrhage. Neurology 82:126-134.

Zehnder A, Fisch U, Hirt A, Niggli FK, Simon A, Ozsahin H, Schlapbach LJ and Ammann RA (2009) Prognosis in pediatric hematologic malignancies is associated with serum concentration of mannosebinding lectin-associated serine protease-2 (MASP-2). Pediatr Blood Cancer 53:53-57.

Zhang H, Penninger JM, Li Y, Zhong N and Slutsky AS (2020a) Angiotensin-converting enzyme 2 (ACE2) as a SARS-CoV-2 receptor: Molecular mechanisms and potential therapeutic target. Intensive Care Med 46:586-590.

Zhang L, Yan X, Fan Q, Liu H, Liu X, Liu Z and Zhang Z (2020b) D-dimer levels on admission to predict in-hospital mortality in patients with Covid-19. J Thromb Haemost 18:1324-1329.

Zhang L, Zhu F, Xie L, Wang C, Wang J, Chen R, Jia P, Guan HQ, Peng L, Chen Y, et al. (2020c) Clinical characteristics of COVID-19-infected cancer patients: a retrospective case study in three hospitals within Wuhan, China. Ann Oncol 31:894-901.

Zhang T, Li J and Cao S (2020d) Prognostic value of left ventricular global longitudinal strain in chronic kidney disease patients: A systematic review and meta-analysis. Int Urol Nephrol. 52:1747-1756.

Zhang Y, Xiao M, Zhang S, Xia P, Cao W, Jiang W, Chen H, Ding X, Zhao H, Zhang H, et al. (2020e) Coagulopathy and antiphospholipid antibodies in patients with Covid-19. N Engl J Med 382:e38.

Zhao Q, Meng M, Kumar R, Wu Y, Huang J, Lian N, Deng Y and Lin S (2020) The impact of COPD and smoking history on the severity of Covid-19: A systemic review and meta-analysis. J Med Virol 92:1915-1921.

Zhou F, Liu Y-M, Xie J, Li H, Lei F, Yang H, Qin J-J, Cai J, Zhang X-J, Wu B, et al. (2020a) Comparative impacts of angiotensin converting enzyme inhibitors versus angiotensin II receptor blockers on the risk of COVID-19 mortality. Hypertension 76:e15-e17.

Zhou F, Yu T, Du R, Fan G, Liu Y, Liu Z, Xiang J, Wang Y, Song $\mathrm{B}, \mathrm{Gu} \mathrm{X}$, et al. (2020b) Clinical course and risk factors for mortality of adult inpatients with COVID-19 in Wuhan, China: A retrospective cohort study. Lancet 395:1054-1062.

Zhou P, Yang X-L, Wang X-G, Hu B, Zhang L, Zhang W, Si H-R, Zhu Y, Li B, Huang C-L, et al. (2020c) A pneumonia outbreak associated with a new coronavirus of probable bat origin. Nature 579:270-273.

Zhou Y, Lu K, Pfefferle S, Bertram S, Glowacka I, Drosten C, Pöhlmann S and Simmons G (2010) A single asparaginelinked glycosylation site of the severe acute respiratory syndrome coronavirus spike glycoprotein facilitates inhibition 
by mannose-binding lectin through multiple mechanisms. J Virol 84:8753-8764.

Zhu J, Ji P, Pang J, Zhong Z, Li H, He C, Zhang J and Zhao C (2020) Clinical characteristics of 3,062 COVID-19 patients: A metaanalysis. J Med Virol 92:1902-1914.

\section{Internet Resources}

Arquivo Brasileiro Online de Mutações (ABraOM), http://abraom. ib.usp.br/index.php, (accessed 14 July 2020).

Brasil - Ministério da Saúde - Boletim Epidemiológico de HIV/ AIDS 2019, http:/www.aids.gov.br/pt-br/pub/2019/boletimepidemiologico-de-hivaids-2019, (accessed 12 July 2020).

Brasil - Ministério da Saúde - Vigilância de fatores de risco e proteção para doenças crônicas por inquérito telefônico 2017 (VIGITEL 2017), https://bvsms.saude.gov.br/bvs/publicacoes/vigitel brasil 2017 vigilancia fatores riscos.pdf, (accessed in 5 July 2020).
Ensembl - Genome Browser, https:/www.ensembl.org/index.html, (accessed 12 July 2020).

GTEx Portal, https://gtexportal.org/home/, (accessed 12 July 2020).

World Health Organization (WHO) - Coronavirus Disease (COVID-19) weekly epidemiological update, https://www.who.int/docs/ default-source/coronaviruse/situation-reports/20201012-weeklyepi-update-9.pdf (accessed 16th October 2020).

World Health Organization (WHO) - HIV, https://www.who.int/hiv/ data/en/, (accessed 12 July 2020c).

World Health Organization (WHO) - Hypertension, https://www. who.int/health-topics/hypertension/\#tab $=$ tab_1, (accessed 5 July 2020b). 